\title{
COMMENTS
}

\section{PROTECTION FROM PROTECTION: SECTION 1983 AND THE ADA'S IMPLICATIONS FOR DEVISING A RACE-CONSCIOUS POLICE MISCONDUCT STATUTE}

\author{
THORNE CLARK $^{\dagger}$ \\ "In the dome the prisoner waited ... shackled to inertia by a great chain \\ of years." \\ - Henry Dumas, black-American author slain by \\ a police officer in a case of "mistaken identity"
}

\section{INTRODUCTION}

Henry Dumas was no prophet; he merely illustrated what was and is readily apparent to those inclined or forced to consider the extent and the impact of racism in daily life. Before he was shot to death in a subway by a mistaken New York City police officer in 1968, ${ }^{2}$ Dumas wrote stories that explored themes central to the experiences of many black persons in the United States-including the prevalence of misconduct by law enforcement officers.' His characters' words are apro-

${ }^{\dagger}$ B.A. 1998, Columbia University; J.D. Candidate 2002, University of Pennsylvania. Many people deserve thanks for making this Comment complete, with the understanding that any errors lingering herein are my own and that the views presented do not necessarily reflect those of anyone other than the author. I would like to thank the members of the National Police Accountability Project of the National Lawyers Guild for their critical input and advice. I would also like to extend a special thanks to Aaron Frishberg, Esq., for offering his advice and his time despite a busy schedule of serving justice, and to my parents and Professor Regina Austin for their invaluable insights and suggestions. The Associate Editors' hard work and attention to detail were essential. Finally, thanks to Ian, Ben, and Darin for their fraternal support and motivation, and to Valmik, Corben, Keeley, and all others whose experiences offer a vivid testament to the fact that lines are still drawn.

1 Henry Dumas, The Marchers, in Goodbye, SweEtwater: New ANd Selected STORIES 177, 177 (Eugene B. Redmond ed., 1988) [hereinafter SWEETWATER].

${ }^{2}$ See Eugene B. Redmond, Introduction to SWEETWATER, supra note 1, at xi, xi (describing Dumas's "violent death ... deep in the Harlem subway . . shot by a white policeman, under what still remain unclarified circumstances").

${ }^{3}$ "Many of you want to know what to tell your children when they ask you why you let the policeman hit you.... I am the most law-abiding citizen. But I'm talking about 
pos in a future he did not live to see, narrating scenarios that are still descriptive of the present American social landscape. Describing a young black man's encounter with four white men led by a local law enforcement officer, he wrote: "To have looked at them would have been too much. Four centuries of black eyes burning into four weak white men . . . would've set the whole earth on fire." Nonetheless, Dumas was not a prophet, because many people of color do not need divination to make them privy to the dangers of living in the United States as a nonwhite person. Many people of color, as a matter of course, can and do reasonably expect interactions with the police to be unsafe. Dumas was therefore simply a writer with a sound understanding of American perceptions of race and the situations that are likely to occur in their wake. Forty years later, Dumas's four weak white men are no longer necessarily going to be weak, nor white, nor men, but they often are. And errant police officers still enjoy many of the legal protections afforded them before the Civil Rights movement.

Critical Race Theorists and their sympathizers have established a large body of literature suggesting that the legal advances of the Civil Rights movement, while important, do not adequately protect the rights of people of color in practice, largely because they are diluted by a colorblind approach ${ }^{5}$ to legal conflicts that is often unjust when

conditions that require careful examination .... [A] close look, a breaking of things down into component parts ...." HENRY DUMAS, Harlem, in SWEETWATER, supra note 1 , at $185,190$.

${ }^{4}$ HENRY DUMAS, Fon, in SWEETWATER, supra note 1, at 99, 111 (alteration in original).

${ }^{5}$ The term "colorblind approach" refers to the notion that race should not be considered formally in legal conflicts, and that justice can prevail without addressing racial categories explicitly. See generally Neil Gotanda, A Critique of "Our Constitution Is Color-Blind", 44 STAN. L. REv. 1 (1991) (discussing the United States Supreme Court's use of colorblind constitutionalism). The metaphor "colorblind" derives from Justice Harlan's dissent in Plessy v. Ferguson, 163 U.S. 537 (1896), in which he stated:

$[I] n$ view of the constitution, in the eye of the law, there is in this country no superior, dominant, ruling class of citizens. There is no caste here. Our constitution is color-blind, and neither knows nor tolerates classes among citizens. In respect of civil rights, all citizens are equal before the law.

Id. at 559. Harlan's introduction of the metaphor illustrates that colorblindness is not synonymous with a benign concern for people of color, stating in the same paragraph that

[t] he white race deems itself to be the dominant race in this country. And so it is, in prestige, in achievements, in education, in wealth, and in power. So, I doubt not, it will continue to be for all time, if it remains true to its great heritage, and holds fast to the principles of constitutional liberty. Id. 
applied. ${ }^{6}$ They argue that race consciousness is a valid and integral element of human interaction, and that vilifying race consciousness in the law is an artifact of a system of justice that devalues the importance of race, and often dismisses the presence of racism in the first place. ${ }^{7}$ Police misconduct has emerged as one manifestation of pervasive racism in the United States. ${ }^{8}$ Nonetheless, it is still viewed as a

${ }^{6}$ See, e.g., David Cole, No EQual Justice: RaCe and Class in the American CRIMINAL JUSTICE SYSTEM 9 (1999) ("To suggest that a 'color-blind' set of rules is sufficient is to ignore the lion's share of inequality that pervades the criminal justice system today. The disparities I discuss are built into the very structure and doctrine of our criminal justice system."); CRITICAL RACE THEORY: THE KeY WRITINGS THAT FORMED THE MOVEMENT (Kimberlé Crenshaw et al. eds., 1995) [hereinafter KEY WRITINGS] (offering a selection of prominent Critical Race Theory writings).

See, e.g., Introduction to KEY WRITINGS, supra note 6, at xiii, xv ("Racial justice was embraced in the American mainstream . . . by treating the exercise of racial power as rare and aberrational rather than as systemic and ingrained.").

${ }^{8}$ People of color are disproportionately targeted by police misconduct. See, e.g., JOHN L. BuRris, BLue vs. Black: LET'S END THE CONFLICT BETWEEN COPS AND MINORITIES 1-2 (1999) (sharing his experience as a civil rights attorney handling police misconduct cases with "blacks, Hispanics, Asians, even whites," adding that "[n]o single race can lay sole claim to the experience of humiliation. But mostly I've seen it with blacks"); Cole, supra note 6, at 22 ("A survey of the Los Angeles Police Department found that one-quarter of the 650 officers responding agreed that 'racial bias (prejudice) on the part of officers toward minority citizens currently exists and ... an officer's prejudice toward the suspect's race may lead to the use of excessive force.");

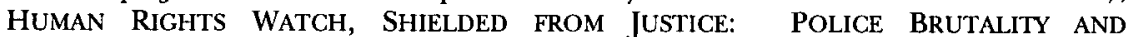
ACCOUNTABILITY IN THE UNITED STATES 39-43 (1998) [hereinafter HuMAN RIGHTS WATCH] (noting that "minorities have alleged human rights violations by police more frequently than white residents and far out of proportion to their representation in those cities," and that the 1991 Christopher Commission "show[s] that race still plays a central role in the use of excessive force"); PETER Verniero \& PAUL H. ZoubeK,

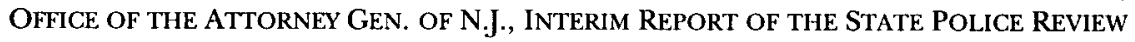
Team Regarding the allegations of RaGial Profiling 4 (1999) [hereinafter INTERIM REPORT] (citing the Attorney General of New Jersey as admitting that "minority motorists have been treated differently than non-minority motorists . . . on the New Jersey Turnpike" and that the "problem of disparate treatment is real"); see also Marjorie Cohn, The Disparate Impact of the Drug War on Minorities, 55 GUILD PRAC. 199, 199 (1998) (arguing that the "War on Drugs has become a war on minorities," evinced by, among other things, police harassment of individuals for "driving while black" and the fact that while "[b]lacks constitute only 11 percent of drug users in this country ... [they] comprise nearly 37 percent of people arrested for drug violations"); Evan Stark, The Myth of Black Violence, N.Y. Times, July 18, 1990, at A21 ("When white and black teen-agers commit the same offense, police are seven times more likely to charge black teen-agers with a felony, and courts are more likely to imprison the teen-ager."). See generally MiCHAEL AVERY ET AL., POlice MisConduct: LAW AND LITIGATION \$ 2:5 (3d ed. 1996) (describing statistical studies of highway stops revealing that, although whites and African Americans violate traffic laws at almost equal rates, cars with AfricanAmerican passengers or drivers were pulled over far more often than whites, even accounting for the relative number of white and African-American drivers on the road). The authors also describe analyses indicating that there are "statistically significant dis- 
rare, if unfortunate, occurrence by whites. ${ }^{9}$ Even if incidents of mis-

parities in the stop rates of blacks and Hispanics versus those of whites, even after differential crime rates among different racial and ethnic groups and among precincts had been factored out through regression analyses." AVERY ET AL., supra, \$ 2:5. This disproportionate targeting is often explicitly racist in nature. David Cole provides a powerful example, noting that "the Louisiana State Police Department's training film explicitly exhorts officers to use traffic stops to conduct narcotics searches of 'males of foreign nationalities, mainly Cubans, Colombians, Puerto Ricans, or other swarthy outlanders."' COLE, supra note 6, at 41 (footnote omitted); see also STOLEN LIVES: KiLled BY LAW ENFORCEMENT (October 22 Coalition to Stop Brutality et al. eds., 2d ed. 1999) [hereinafter STOLEN LIVES] (cataloguing recent deaths that occurred as a result of racially discriminatory police misconduct). Including relations with police as one vector of potential racism, one study found that "almost $60 \%$ of African Americans perceive that they have been discriminated against in the past 3 years." Clifford L. Broman et al., The Experience and Consequences of Perceived Racial Discrimination: A Study of African Americans, $26 \mathrm{~J}$. BLACK PSYCHOL. 165, 175 (2000). Other studies reveal much higher figures with respect to racism generally. One such study reported that $96 \%$ of the study participants reported experiencing racist discrimination in the past year. Elizabeth A. Klonoff \& Hope Landrine, Cross-Validation of the Schedule of Racist Events, 25 J. BLACK PSYCHOL. 231, 234 (1999).

Police do not always have an affirmative duty to assist private citizens who are in danger. See, e.g., DeShaney v. Winnebago County Dep't of Soc. Servs., 489 U.S. 189, 191 (1989) (holding that a police detective's failure to provide petitioner with adequate protection against his father's violence did not violate petitioner's rights under the substantive component of the Due Process Clause). This increases the risk that bias may also occur if police exercise their discretion not to intervene to help people of color in distress.

Police misconduct can be particularly harmful to people of color who are already reticent about reporting to the police for other reasons, such as rape victims, women subject to domestic violence, and people who have been assaulted for being perceived as homosexual, bisexual, or transgendered. Police misconduct may make such victims even less likely to trust officers. See Kimberlé Williams Crenshaw, Mapping the Margins: Intersectionality, Identity Politics, and Violence Against Women of Color, 43 STAN. L. REV. 1241, 1257 (1991) ("Women of color are often reluctant to call the police [to report domestic violence], a hesitancy likely due to a general unwillingness among people of color to subject their private lives to the scrutiny and control of a police force that is frequently hostile."); Jennifer Wriggins, Note, Rape, Racism, and the Law, 6 Harv. WOMEN's L.J. 103, 122-23 n.122 (1983) (discussing evidence "suggesting that police behavior may be an especial deterrent to Black women's reporting" rapes, especially rapes by white men). The officers themselves are less likely to take their crime reports seriously, and may actively harass these groups. See Darren Lenard Hutchinson, Ignoring the Sexualization of Race, 47 BUFF. L. REV. 1, 35 (1999) (noting that "[m] any gays and lesbians ... distrust law enforcement due to a history of victimization and harassment by police officers," and that "race might increase the vulnerability of gays, lesbians, bisexuals and the transgendered of color to homophobic violence and subject them to additional harassment and further abuse by police officers when they report their victimization"); Wriggins, supra, at 104 n.2 (noting that "police often decide not to pursue rape complaints which may be valid, especially if the complainant is Black").

${ }^{9}$ See COLE, supra note 6, at 7 ("White Americans are not likely to want to believe [the claim that our criminal justice system depends on inequality]. The principle that all are equal before the law is perhaps the most basic in American law."). Cole argues that the Supreme Court adopts standards that "presume[] that we all have the same set 
conduct were rare, however, current colorblind statutory interpretations still play a noxious role by supporting a judicial refusal to acknowledge that racism is pervasive, that it forces many people of color to tread carefully in their day-to-day lives, and that this is relevant when police misconduct does occur. This is dangerous for people of color because judges ensure that their rational and innocent reactions to police may get them shot. ${ }^{10}$

This Comment compares two statutes offering plaintiffs causes of action against police, 42 U.S.C. $\S 1983^{11}$ and the Americans with Disabilities Act of 1990 (ADA), ${ }^{12}$ to explore how a colorblind approach to civil rights has left plaintiffs of color ${ }^{13}$ in the lurch with respect to police misconduct, and to solicit the creation of a race-conscious police misconduct statute. ${ }^{14}$

of experiences vis-à-vis the police, and that none of us has any reason to feel coerced by an 'ordinary' police encounter." Id. at 27. Whites, in general, are significantly less likely than blacks to perceive that racial discrimination exists against people of color. See also, e.g., LEE SIGELMAN \& SUSAN WELCH, BlaCK AMERICANS' VIEWS OF RACIAL INEQUALITY: THE DREAM DEFERRED 53 (1991) (indicating that black Americans perceive racism to be more prevalent than white Americans); Lawrence Bobo \& James $\mathbf{R}$. Kluegel, Opposition to Race-Targeting: Self-Interest, Stratification Ideology, or Racial Altiludes, 58 AM. SOC. REV. 443 (1993) (finding that most whites in America tend to endorse the notion of equality in principle, but are opposed to many policies designed to enhance opportunities among blacks).

${ }^{10}$ For a discussion of judicial responsibility in the matter of police misconduct, see infra notes 208-13, 223, 234, 238-61, 269-70, 274-77 and accompanying text and Parts IV.C.1-2. For a lengthy, but by no means exhaustive, catalog of recent deaths due to police misconduct, see STOLEN LIVES, supra note 8, which provides the age and race of victims, where they were killed, and the circumstances surrounding their deaths. Many of the deaths listed reflect rational and innocent responses to the police. The source is helpful for understanding the nature of police abuse because in many cases it includes the police officers' stated rationale for using deadly force. This is useful for indicating that even when responses to the police are belligerent, the force the police use in response is excessive and often explicitly racist.

11 For the text of $\$ 1983$, see infra note 79.

1242 U.S.C. $\$ \$ 12101-12213$ (1994). For a discussion of the text and purpose of the $\mathrm{ADA}$, see infra notes 83-95, 128-31 and accompanying text.

is At the risk of essentializing the experiences of nonwhites, the terms "plaintiff of color" and "people of color" are used throughout this Comment. Much of the literature cited refers explicitly to black people. The use of these sources is not intended to be understood as excluding the presence or validity of literature addressing other racial identities of color. While acknowledging that the effects of racism on people of different races, and among people of the same race, vary in innumerable ways, this Comment seeks to address broad problems in police misconduct law that generally affect most nonwhite groups.

14 This Comment is not intended to prioritize the interests of people of color above the interests of persons with disabilities, or to suggest that those interests are necessarily mutually exclusive. Nor does it argue for limitations on the tools available to individuals with disabilities in police misconduct suits. Rather, the purpose of this 
When a plaintiff in a police misconduct suit has a disability, such as deafness or post-traumatic stress disorder (PTSD), a red flag goes up warning that a police officer's failure to take adequately the disability into consideration may be culpable. ${ }^{15}$ The plaintiff's disability will prompt her attorney to consider making a claim under the ADA, and the judge hearing the case will be obligated to consider a claim by the plaintiff that the misconduct was attributable in part to her disability. By contrast, when a plaintiff in a police misconduct suit is a person of color, no red flag is raised on account of that. In fact, not only do judges abstain from noting how race influences the actions of police officers-they are actively criticized for acknowledging any societal racial influence at all. ${ }^{16}$ This occurs despite the fact that race is often the focal point of misconduct in a way that disability status is not. (Persons with disabilities are not the targets of police harassment by virtue of their disabled status, but because of behavior that their disability makes manifest. People of color are often targeted precisely because they are not white, irrespective of their behavior.) The plaintiff of color can raise a $\S 1983$ claim, but such a claim is restricted by the prevailing understanding of equal protection that has developed over

Comment is to use the ADA as a template with which to illustrate that any system offering protection against police misconduct, the efficacy of which is more dependent upon a plaintiff proving that her actions are reasonable (because they fall within enumerated types of legitimizing conduct) than proving that the defendant officer's actions are abusive, is insufficient and results in bias against the very group that is most affected by police misconduct: people of color.

Nor should this Comment be understood as being written on behalf of people of color, nor to suggest that people of color are necessarily likely to favor a race-conscious approach to law. Several notable scholars of color have criticized race-conscious approaches. See, for example, Randall Kennedy, an African American, who in his article Racial Critiques of Legal Academia, 102 HARV. L. REV. 1745 (1989), criticizes aspects of popular Critical Race Theorists' writings. Id. at 1749. Others emphasize that raceconscious approaches to law need not be mutually exclusive with race-neutral remedies. See, e.g., Jayne Chong-Soon Lee, Navigating the Topology of Race, in KEY WRITINGS, supra note 6, at 441, 447 ("Abandoning one set of definitions entirely may deprive us of useful tools in the struggle against racism.").

${ }_{15}$ Consider, for example, Lewis $v$. Truitt, 960 F. Supp. 175 (S.D. Ind. 1997), in which the court applied the ADA to the arrest of a deaf man for not responding to the arresting officers. The court held that "a plaintiff may recover under the ADA where he can show that (1) he was disabled, (2) the defendants knew or should have known he was disabled, and (3) the defendants arrested him because of legal conduct related to his disability." Id. at 178; see also infra notes 88, $92-97$ and accompanying text (discussing pertinent portions of the ADA and courts' recognition of the validity of hearing ADA claims against law enforcement entities).

${ }^{16}$ See infra notes $240-45$ (discussing a recent case where a judge recognized the prevalence of corruption and racism among police officers and subsequently vacated his original decision amid claims that the judge engaged in judicial activism). 
the last few decades: that the closest approximation of justice is manifest by a colorblind approach to conflicts.

To illustrate the problem, consider two variations on a common scenario: An individual, person $X$, is walking down the street in an area where it is $X$ 's experience that police often harass or embarrass pedestrians, especially pedestrians who are not white. A squad car pulls up, and $X$ turns around and walks in the other direction to avoid attracting the attention of the police. The police officers apprehend $X$, claiming that $X$ 's behavior was "odd," despite the history of police misconduct against innocent suspects in this area.

In the first variation, assume that $X\left(X_{l}\right)$ is of indeterminate race, and that the officers admit to recognizing $X_{1}$ as a local war veteran. Assume also that the officers are aware that $X_{l}$ suffers from a stress disorder as the result of his combat experience that makes $X_{l}$ nervous and asocial when confronted by aggressive behavior, particularly from persons carrying weapons. If the officers refuse to take steps to communicate with $X_{I}$ and then base their decision to apprehend $X_{I}$ on his failure to respond to the officers appropriately, $X_{1}$ may have a valid claim against the police under the ADA. ${ }^{17}$ Although $X_{1}$ 's behavior would be considered atypical, it would be considered legitimate given $X_{1}$ 's stress disorder.

By contrast, assume that in the second variation $X\left(X_{2}\right)$ is a person of color. $X_{2}$ has no diagnosed stress disorder. The police, however, recognize $X_{2}$ because they have stopped him on several occasions without reasonable suspicion, even though they have never arrested him. $X_{2}$ has been visibly disturbed by such stops in the past, and the police are aware of this. Nonetheless, the officers insist that $X_{2}$ 's decision to avoid the police is "odd," verbally and physically abused, it is unlikely that $X_{2}$ will prevail if he files suit charging police misconduct. ${ }^{19}$

A potentially self-reinforcing abuse is apparent. $X_{l}$ is prone to adverse reactions around police because of an unrelated series of events (his combat experience), while $X_{2}$ is prone to adverse reactions to po-

${ }^{17}$ See infra notes 93-97, 126 and accompanying text (noting that the ADA has been applied to law enforcement entities); infra notes 127, 144-48, 151 (noting that the ADA may also protect disabled individuals with certain mental disorders).

${ }^{18}$ See infra notes 240-46 and accompanying text (discussing a Second Circuit opinion indicating that an officer's claim that a person's behavior was "odd" satisfies the requirement of reasonable suspicion, even if the officer's precinct is publicly regarded as being infamous for its corrupt police). lice).

See infra Part I (discussing the difficulty of prevailing in a suit against the po- 
lice for reasons directly attributable to the police (perhaps even the arresting officers themselves). Should $X_{2}$ bring his ordeal to the attention of the courts, his reactions will most likely be deemed unreasonable. $^{20}$ In effect, the more intimidating and brutal the police are, the more likely it becomes that they will incite what the courts have deemed "odd" reactions from the people they approach. Therefore, it is more likely that the police will be considered justified in their harassment of innocent people.

A statutory gap becomes apparent. Racism, whether overt or subtle, can exact a heavy psychological toll on people of color. ${ }^{21}$ Police misconduct is a prevalent manifestation of racism in this country. ${ }^{22}$ Although the ADA is a potentially effective tool for pursuing police misconduct suits generally, on behalf of those suffering from some psychological traumas, plaintiffs of color cannot garner the protections of the ADA by virtue of the trauma suffered as a result of racially discriminatory police misconduct. On the other hand, while $\S 1983$ purportedly protects claimants from racial discrimination generally, $\S 1983$ is procedurally impotent when applied against police officers.

These statutory deficiencies have resulted in an inequitable status quo. Certain categories of plaintiffs, such as disabled white individuals, have tools available to them with which to approach police misconduct suits that are not available to most people of color (whether disabled or not). Judges are statutorily obligated to consider aspects of plaintiff-police interactions in a way that often benefits white plaintiffs and plaintiffs with disabilities in police misconduct suits, ${ }^{23}$ but are not similarly obligated to consider how the plaintiff's race may affect these interactions. ${ }^{24}$

The statutory incongruity between the ADA and $\S 1983$ implicitly offers an inappropriate incentive to plaintiffs' attorneys to portray

${ }^{20}$ See infra Part IV.B.2 (discussing judges' perceptions of the reactions of people of color to police).

${ }^{21}$ Discussing black men in particular, psychiatrists note that " $[\mathrm{t}]$ he racist tradition is pervasive and envelops every American.... [I]t constitutes a heavy psychological burden." William H. Grier \& Price M. Cobbs, Bl.ack RaGe 71 (1968).

${ }_{22}^{22}$ See supra note 8 (describing types and giving examples of such misconduct).

${ }^{23}$ See infra Part III (discussing how the benefits of the ADA are often available to persons subject to mental and emotional stressors to which whites are exposed, but not to persons subject to stressors to which people of color are more likely to be exposed).

${ }^{24}$ This is true despite evidence that experiences particular to people of color, by virtue of being exposed to racially discriminatory stressors, may affect plaintiff-police interactions to an equal or greater extent than factors affecting primarily white and disabled plaintiffs. Id. 
their clients as primarily atypical individuals without addressing race as a distinguishing factor. It may entice plaintiffs' attorneys to characterize their clients as persons with disabilities (also considered by Congress to be a minority ${ }^{25}$ ), portraying their clients' identities such that they correspond with prescribed categories of individuals protected by the ADA.

As a result, the present state of the law as it pertains to police misconduct has serious adverse consequences for plaintiffs of color, both on the individual level and on the societal level. Individually, persons suffering from stress disorders as a result of particular instances of racial discrimination have no direct recourse to the ADA. The impact of racism is dismissed.

The societal response to misconduct is to draw judicial attention away from the actions of the defendant police officers and departments, emphasizing instead the plaintiff's ability to legitimize behavior (his or her own) that should be understood as reasonable. This supports a logic whereby victims of police misconduct must prove the reasonableness of their aversion to racism before judges will question the impropriety of racist police protocol. It also supports the mistaken conclusion that only persons who develop mental illnesses have actionable claims against the police. Furthermore, telescoping the critical focus on to the behavior of one plaintiff, instead of the behavior of an institution such as a police department, misconstrues the nature of racism. It suggests that the plaintiff's experience is a solitary deviation from an otherwise just and equal status quo, instead of recognizing that racism is institutionalized to the extent that it permeates such a basic staple of civic structure as law enforcement.

This neglect of the role that race plays in police encounters with victims of color can be mitigated by statutory revision. Two solutions present themselves. The first focuses on individual experiences of racism and the behavior of the plaintiff. It would afford the substantive

${ }^{25}$ Infra notes 128-31 and accompanying text. This Comment discusses how the reactions of some people of color to police are characterized as atypical, and in doing so compares this characterization to that of the behavior of persons with disabilities, whose behavior is also implied to be atypical-that is, in the minority. This Comment addresses a prevalent confusion of the notion of "atypical" with the notion of "unreasonable" identified by Jody D. Armour and criticizes its occurrence when it emerges with respect to people of color in police misconduct suits. See infra note 227 and accompanying text (elaborating on Armour's distinction). While this Comment addresses this confusion in the context of circumstances faced by people of color, the arguments put forth below should not be understood to condone any such confusion of atypicality and unreasonableness as applied to persons with disabilities. Any inquiry addressing that issue with the attention it merits is beyond the scope of this Comment. 
protections of the ADA to more people of color by expanding the definitions of mental illnesses (such as PTSD) to recognize disorders that arise in response to racist environments. The second solution focuses on societal racism and the behavior of the errant police defendant. Under the second solution, the procedural advantages unique to the ADA, which make it a potentially more effective statute for pursuing police misconduct claims, would be made more broadly available to claimants of color to the benefit of citizens and police officers alike. Even when plaintiffs' experiences of racism do not place them within the rubric of the $\mathrm{ADA}$, the second solution recognizes police misconduct as a serious problem in need of correction. The two solutions are not necessarily mutually exclusive. Both solutions embrace a race-conscious approach to the law rather than the prevailing colorblind approach.

Part I begins by discussing why the traditional criminal and civil remedies for police misconduct are inadequate. Part II describes the procedural advantages available to claimants under the ADA that are not available under traditional civil rights statutes. Part III illustrates how the $\mathrm{ADA}$ is interpreted such that people of color have unequal access to the status of a viable claimant under the ADA, discussing the ADA's treatment of PTSD in particular. Part IV critiques the practical and policy implications of the disparity between the efficacy of the ADA and the efficacy of the statutory avenues currently open to plaintiffs of color. Part IV also suggests making the advantageous procedural provisions of the ADA more broadly available to plaintiffs of color charging the police with misconduct. Finally, Part $\mathrm{V}$ anticipates and addresses some criticisms of making the statutory changes suggested in Part IV.

\section{TRADITIONAL CRIMINAL AND CIVIL REMEDIES ARE INEFFECTIVE FOR POLICE MISCONDUCT LITIGATION}

\section{A. The Problems of Criminal Prosecution of Police Misconduct}

Criminal prosecution of police officers and departments is highly problematic for plaintiffs, and is unlikely to result in convictions. ${ }^{26}$ Because such prosecutions are so difficult they usually do not succeed

${ }^{26}$ HUMAN RIGHTS WATCH, supra note 8, at 86, 97 (listing reasons why prosecutors are unwilling to pursue cases against police officers, and noting that "officers who are occasionally prosecuted successfully ... do not generally receive long sentences"). 
in improving human rights practices. ${ }^{27}$ In New York, for instance, despite scores of fatal shootings in the last two decades, not one officer was convicted of homicide for an on-duty shooting between 1977 and $1995 .^{28}$

This is attributable, in part, to the fact that local criminal prosecutions of police officers for excessive force are rare. ${ }^{29}$ Local prosecutors may be hesitant to pursue cases against suspected abusive police officers for several reasons. ${ }^{30}$ First, prosecutors may not be willing to jeopardize the traditionally close relationship between district attorneys and the local police, who work together to prosecute other alleged criminals. Human Rights Watch, an organization dedicated to protecting human rights globally, recently turned its attention to the United States, evaluating the prevalence of police misconduct in fourteen major American cities. ${ }^{31}$ Its studies led to the conclusion that "[ $t]$ here is a natural conflict of interest when district attorneys-who typically work closely with the police to bring cases against suspected criminals-are faced with prosecuting those same officers." ${ }^{, 22}$ In jurisdictions where prosecutors are elected, prosecutions of individual officers can engender a lack of support among police unions, which may subsequently cost a prosecutor an election. ${ }^{3.3}$ Prosecutions of police officers are also rare because it is difficult to convince juries that an officer committed a crime, ${ }^{34}$ and did not merely make an understandable mistake. ${ }^{35}$ Third, in some jurisdictions, there are special proceed-

${ }^{27}$ Id. at 85 .

${ }^{28}$ Id. at 87 .

${ }^{29}$ Id. at 85. In New York City, the Department Advocate's Office regularly fails to refer criminal cases of misconduct to the District Attorney. MARK GREEN, OfFICE OF THE New York Cíty Pub. Advocate \& THE ACcountability Project, Disciplining POLICE: SOlving THE PROBLEM OF POLICE Misconduct 51 (2000).

${ }^{30}$ Human Rights WATCH, supra note 8 , at 86.

${ }^{91}$ See id. at 1 ("The cities examined are: Atlanta, Boston, Chicago, Detroit, Indianapolis, Los Angeles, Minneapolis, New Orleans, New York, Philadelphia, Portland, Providence, San Francisco, and Washington, D.C.").

${ }^{32}$ See $i d$. at 86 (noting "a particular reticence in bringing charges against officers who have been 'productive' and who have worked closely with the district attorney's office").

${ }^{33}$ See id. at 38, 86 ("In some jurisdictions, district attorneys are elected and are aware that the powerful police unions and their supporters may withdraw their support if a police officer is prosecuted.").

${ }^{34}$ See ColE, supra note 6, at 8 ("The rhetoric of the criminal justice system sends the message that our society carefully protects everyone's constitutional rights, but in practice the rules assure that law enforcement prerogatives will generally prevail over the rights of minorities and the poor.").

${ }^{35}$ See HumAN RIGHTS WATCH, supra note 8 , at 86 (commenting that "by only pur- 
ings that provide additional protections for police officers. ${ }^{36}$ Finally, there is a dearth of information about systems for reviewing possibly prosecutable crimes. ${ }^{37}$

When local prosecutors decline to pursue police misconduct cases, the federal government has a responsibility to step in if the plaintiff's civil rights have been violated. ${ }^{98}$ Commentators have identified a trend of federal passivity to police misconduct. ${ }^{39}$ Federal prosecutors rarely take on cases in which the local prosecutor attempted to indict but failed. ${ }^{40}$ Even when federal officials do intervene to investigate actively cases that local prosecutors declined, prosecutions do not fare much better than they do at the local level due to strategic problems that hamper convictions. For example, Steven D. Clymer, a law professor at Cornell University, notes that it is difficult to prove police misconduct in court. ${ }^{41}$ Jurors historically presume guilt or innocence in favor of the police officers. ${ }^{42}$ Further, federal prosecutors rely on the FBI to investigate local police misconduct allegations, but inquiries may be limited to information provided by the very same local police agency that is itself under scrutiny. ${ }^{43}$

Police misconduct, therefore, often is immune to successful criminal prosecution. In 1996, the Civil Rights Division of the United States Justice Department received 11,721 complaints regarding instances of police misconduct. ${ }^{44}$ Only twenty-two of these complaints were filed as cases of official misconduct. ${ }^{45}$ Considering other types of cases prosecuted by the Civil Rights Division, this rate of conviction underscores the singularly low rate of prosecutorial success in the police misconduct context: while there is nearly a $100 \%$ rate of success for cases that are fully prosecuted by the Civil Rights Division not involving official misconduct, the conviction rate of police cases in 1996

suing rare, overwhelmingly strong cases, the deterrent effect of criminal prosecution of officers is undermined significantly").

\footnotetext{
Id.

${ }^{37}$ Id. at $86,106-10$.

Id. at 89 .
}

${ }^{39}$ See id. at 91 (maintaining that "lack of funding and staffing at the Criminal Section of the Civil Rights Division [of the Justice Department] ... reflects the government's overall lack of commitment to prosecuting these types of cases").

40 . at 99 . $62,64)$.

${ }^{41}$ Id. at 85 (citing Mark Curriden, When Good Cops Go Bad, A.B.A. J., May 1996, at
Id.
4.3 Id. at 96.
44 Id. at 93 .
${ }^{45}$ Id. 
was only $64 \% .^{46}$

Law enforcement officers also account for almost all the acquittals in cases prosecuted by the Civil Rights Division. ${ }^{47}$ When officers are prosecuted, but subsequently acquitted, they almost always avoid any further discipline or they get their jobs back through arbitration. ${ }^{48}$ Firing even the most violent officers can be "nearly impossible." When convicted, officers spend little or no time incarcerated. ${ }^{50}$ In New York City, in fact, officers responsible for substantiated complaints of misconduct are more likely to be promoted than dismissed, and the police department awards medals to officers at the same time that those officers are receiving civilian complaints. ${ }^{52}$ Police misconduct clearly is not taken seriously.

\section{B. The Problems of Traditional Civil Prosecution of Police Misconduct}

Given the criminal system's failure to prosecute police misconduct effectively, some victims have turned to the pursuit of civil suits as an option superior to criminal suits." Indeed, "deflecting criticisms regarding the government's failure to fulfill its obligation to ensure the rights of individuals within the United States are protected," government officials themselves laud civil remedies as the most effective

${ }^{40}$ See id. at 94 (pointing out that civil rights cases in general are prosecuted less often than other categories of offenses handled by the Justice Department).

${ }^{4}$ Id. at 103 .

${ }^{48}$ See id. at 72 ("Even in cases where heads of police departments have ordered the dismissal of officers known to be brutal, the officers have won reinstatement, with back pay, through arbitration or court appeals.").

${ }^{49}$ See id. (discussing the findings of a series of investigative articles in the Philadelphia Inquirer that looked at cases occurring between 1992 and 1995).

${ }^{50}$ See id. at 99 (noting that in 1994 and 1995, twenty-five defendants out of ninetysix convicted were sentenced to three months or less in prison).

${ }^{51}$ GREEN, supra note 29 , at 62 .

52 Id. at 64.

${ }^{53}$ See HUMAN RighTS WATCH, supra note 8, at 122 ("Police abuse experts had long recommended giving federal authorities power to bring civil actions against police departments engaging in a pattern or practice of misconduct."). State courts have seen a rise in civil suits for police' misconduct as well. On this point authors Michael Avery, David Rudovsky, and Karen M. Blum note:

With decisions of the United States Supreme Court limiting access of civil rights plaintiffs to the federal courts, the increasing conservatism of lower federal judges, and the liberalization of some state court decisions in the constitutional area, an increasing number of plaintiffs began filing $\$ 1983$ claims in state court in the 1980 s and 1990 s.

AVERY ET AL., supra note $8, \S 2.1$ (citations omitted). 
means for redress in police misconduct cases. ${ }^{54}$ Section 1983 theoretically provides such civil protection. ${ }^{55}$ The statute is understood to serve two purposes when applied in the context of police misconduct: It is meant both to compensate the victims and to hold officers and departments accountable to constitutionally required standards of conduct. ${ }^{56}$ In the end, however, officers whose actions may have been criminal are still free to administer the law as they see fit, and the victim is dismissed, uncompensated. ${ }^{57}$

Several impediments to the success of a typical $\S 1983$ claim have been noted as being particularly problematic. First, the doctrine of qualified immunity "serves to make the civil rights plaintiff's burden almost insurmountable." ${ }^{58}$ Qualified immunity will be available as a defense for an officer "when a reasonable official would not have known that his actions would violate a constitutional right that was 'clearly established' at the time of the incident." 59 The immunity is

54 HUMAN RIGHTS WATCH, supra note 8, at 118.

${ }^{55}$ Section 1983 is meant to provide compensation for federal statutory violations or constitutional deprivations caused by state officials or the operation of state laws. Monroe v. Pape, 365 U.S. 167, 172 (1961).

56) HUMAN RIGHTS WATCH, supra note 8, at 119.

${ }^{57}$ See id. ("Civil lawsuits are limited in important respects that undermine their effectiveness in providing a remedy for past violations and in providing protection against future police abuse.").

${ }_{58}$ James C. Harrington, The ADA and Section 1983: Walking Hand in Hand: Using the Americans with Disabilities Act to Re-open the Civil Rights Door, 19 REV. LITIG. 435, 438 (2000); see also AVERY ET AL., supra note 8, $\$ 3.4$ ("Qualified immunity has emerged as the most significant and problematic defense to claims of civil rights violations. Its development in the Supreme Court has been marked by ad hoc decision making, conflicting rationales, and a high degree of doctrinal manipulation.").

AVERY ET AL., supra note 8, § 3.4; see also Wilson v. Layne, 526 U.S. 603, 615 (1999) (finding that "it was not unreasonable for a police officer in April 1992 to have believed that bringing media observers along during the execution of an arrest warrant ... was lawful," thereby conferring qualified immunity); Siegert v. Gilley, 500 U.S. 226, 232-33 (1991) (holding that protection arises when a public official claims to have acted in an objectively reasonable manner with regard to a law that is not clearly settled); Anderson v. Creighton, 483 U.S. 635, 646 (1987) (declining to "make an exception to the general rule of qualified immunity for cases involving allegedly unlawful warrantless searches of innocent third parties' homes in search of fugitives"); Harlow v. Fitzgerald, 457 U.S. 800, 818 (1982) ("[G]overnment officials performing discretionary functions, generally are shielded from liability for civil damages insofar as their conduct does not violate clearly established [federal] statutory or constitutional rights of which a reasonable person would have known."). The official's subjective motivation is not relevant to the qualified immunity defense. See Harlow, 457 U.S. at 818 (discussing how an analysis of qualified immunity should be limited to the "objective reasonableness of an official's conduct"). The Supreme Court described the test for immunity as laid out in Harlow as a "fair warning standard": if the federal law was clearly established, the official is on notice that violation of that federal law may lead to personal 
"immunity from suit rather than a mere defense to liability." "While juries are supposed to focus on whether the officer's conduct was objectively reasonable," in fact, "they may focus instead on what the officer reasonably believed about the facts. ${ }^{.61}$ The recent decision in Saucier $v$. Katz further confuses the matter of objective reasonableness, in that it seems to add a good faith reasonableness standard to the previous objective reasonableness test. ${ }^{62}$ As a result, "[n]ow we have the police officer's reasonable understanding of how much force is constitutional confusing the issue of how reasonable the conduct is. ${ }^{163}$ Applying qualified immunity to constitutional claims litigated under an objective reasonableness standard gives the official two layers of reasonableness protection: one under the Fourth Amendment, and another under qualified immunity. ${ }^{64}$ "This can lead to the awkward conclusion that the official acted . . . reasonably (for immunity purposes) [, but] unreasonabl[y] (for constitutional purposes) . . .,.65

monetary liability. United States v. Lanier, 520 U.S. 259, 270 (1997).

${ }^{60}$ Mitchell v. Forsyth, 472 U.S. 511, 526 (1985).

${ }^{61}$ HUMAN RIGHTS WATCH, supra note 8, at 120.

${ }^{62}$ E-mail from Aaron Frishberg, Esq., to Thorne Clark (Jan. 7, 2002, 1:49:46 EST) (on file with author). Saucier establishes that after an initial inquiry into whether a constitutional right is violated, "the next, sequential step is to ask whether the right was clearly established .... The relevant, dispositive inquiry is whether it would be clear to a reasonable officer that his conduct was unlawful in the situation he confronted." 533 U.S. 194, 196 (2001) (citation omitted). Saucier rejects the notion that a finding of excessive force precludes the qualified immunity defense: just because an officer's conduct has been determined to be unreasonable under the excessive force analysis does not necessarily mean that a reasonable officer could not have concluded that deadly force was constitutional. Even before Saucier, the objective reasonableness of the force an officer used was an issue. It is hard to determine, in court, what a reasonable officer would find constitutional. See, e.g., Willingham v. Loughnan, 261 F.3d 1178, 1186 n.13 (11th Cir. 2001) (holding that a jury could find the police shooting of plaintiff's decedent to have been constitutionally unreasonable under the Fourth Amendment, but that because there were no earlier cases with similar facts, the officers could not be charged with the knowledge that their actions would violate the plaintiff's rights). Beck v. Ohio, 379 U.S. 89 (1964), holds that good faith on the part of the arresting officers is not enough to override the Fourth Amendment rights of a defendant arrested by the officers without a warrant. That case, however, only addresses the arrestee's rights, not the officer's liability.

${ }^{63}$ E-mail from Aaron Frishberg, Esq., to Thorne Clark (Jan. 22, 2002, 01:55:58 EST) (on file with author). Frishberg adds that lower courts may be more likely to dismiss more plaintiffs' claims, armed with the double-barreled reasonableness standard.

${ }^{64}$ See supra note 62 (explaining the decision in Saucier). The qualified immunity defense applies even when, as in Fourth Amendment challenges to arrests and searches, the constitutional standard itself is an objective reasonableness standard. Anderson v. Creighton, 483 U.S. 635 (1987).

${ }_{65}$ Martin A. Schwartz, Fundamentals of Section 1983 Litigation, in $117 \mathrm{TH}$ ANNUAL 
Based on this standard, police officers usually secure qualified immunity, ${ }^{66}$ and only the most flagrant, shocking conduct-not just inept actions-will defeat qualified immunity. ${ }^{67}$ Having to meet that burden, therefore, greatly decreases the likelihood that a plaintiff's claim will succeed. ${ }^{68}$

Second, the interlocutory appellate mechanism, created by the United States Supreme Court, facilitates review of a denial of summary judgment, in favor of qualified immunity for an official. ${ }^{69}$ Such an appeal significantly delays litigation and may require the plaintiff to overcome a claim of immunity with only minimal opportunities to en-

Section 1983 Civil Rights Litigation 13, 65 (Pli Litig. \& Admin. Practice Course, Handbook Series No. H-665, 2001).

${ }_{66}^{66}$ Harrington, supra note 58, at 438 . The court in Leong $v$. City of Detroit stated: Even if it were concluded, upon resolving ... factual disputes in the plaintiff's favor, that an officer's use of deadly force was unreasonable under the Fourth Amendment, the officer still would be entitled to qualified immunity if, under the present state of the law, a reasonable officer could have concluded-albeit mistakenly - that deadly force was authorized under the circumstances.

151 F. Supp. 2d 858, 864 n.5 (E.D. Mich. 2001); see also Willingham v. Loughnan, 261 F.3d 1178, $1186 \mathrm{n} .13$ (11th Cir. 2001) ("Saucier directly rejects [the] argument that a finding of excessive force precludes the qualified immunity defense. That Defendants' conduct has been ultimately determined to be unreasonable... does not decide whether the law was already clearly established at the time Defendants acted that what they were doing ... necessarily violated federal law."). Even prior to Saucier, officers often secured qualified immunity. See, e.g., Oliver v. Woods, 209 F.3d 1179, 1187 (10th Cir. 2000) (holding that the officer was entitled to qualified immunity for the initial detention and request to the plaintiff to identify himself because he might reasonably have concluded that the suspect had committed a crime, even though the officer testified that as he approached plaintiff, he saw nothing in particular to indicate he was engaged in any crime, and that he knew silent alarms that were tripped at the auto repair shop where plaintiff had just dropped off his car were tripped by innocent people "all the time"); Napier v. Windham, 187 F.3d 177, 188 (1st Cir. 1999) (arguing that an officer is entitled to immunity unless a reasonable officer in his position would have known that the Graham standard labeled his conduct excessive); Gold v. City of Miami, 121 F.3d 1442, 1446 (11th Cir. 1997) (securing qualified immunity for defendant officers); Slattery v. Rizzo, 939 F.2d 213, 215-16 (4th Cir. 1991) (same); Finnegan v. Fountain, 915 F.2d 817, 822-23 (2d Cir. 1990) (same); Brown v. Glossip, 878 F.2d 871, 87374 (5th Cir. 1989) (same); Landrum v. Moats, 576 F.2d 1320, 1327-28 (8th Cir. 1978) (same).

${ }^{67}$ Alton v. Tex. A \& M Univ., 168 F.3d 196, 201 (5th Cir. 1999); see also Snyder v. Trepagnier, 142 F.3d 791, 801 (5th Cir. 1998) (upholding qualified immunity for a police officer who shot an unarmed man in the back at a range of six to ten inches, while the victim was stuck in the mud in a swamp).

${ }_{68}$ Furthermore, "[a]lthough a municipality has no qualified immunity under $\$ 1983$, it may be difficult for plaintiffs to prove the requisite deliberate indifference... when individual defendants prevail on the qualified immunity defense on the ground that the law was not clearly established at the time of the incident." AVERY ET AL., supra note $8, \S 3.23$.

${ }^{69}$ Harrington, supra note 58, at 438. 
gage in discovery. ${ }^{70}$ Thus, rather than establishing that the allegedly guilty officers have operated within the bounds of the law, this mechanism impedes discovery to such an extent that the court is never formally apprised of the officers' inappropriate, or even criminal, action.

Third, while courts may on a rare occasion find municipalities liable, the ruling in Monell v. Department of Social Services of the City of New York $^{71}$ requires that the plaintiff establish a municipality's policy, custom, or longstanding policy-like practice of abuse. ${ }^{72}$ The ruling in Los Angeles $v$. Lyons ${ }^{73}$ requires a showing of a real and immediate likelihood that the alleged misconduct will happen to that particular plaintiff again, thereby reducing the likelihood of enjoining an offensive practice. $^{74}$

Even when remedies are awarded, only actual damages are available, not punitive damages. ${ }^{75}$ Cases involving inadequate police training are particularly problematic since the Supreme Court's imposition in 1989 of a separate "state of mind requirement," which demands that the plaintiffs prove deliberate indifference to abuse on the part of the municipality. ${ }^{76}$

Fourth, the doctrine of sovereign immunity is often applied to police misconduct cases. Suits against state officials in their official capacities are considered suits against that official's office, and are therefore treated as suits against the state itself. ${ }^{77}$ Because sovereign immunity prevents plaintiffs from recovering damages against a state, which is prohibited by the Eleventh Amendment of the United States

${ }^{70}$ See id. (noting also that the appeal saves the officer the time and expense of a defense, and permits her to remain employed).

${ }^{71} 436$ U.S. 658, 690-92 (1978).

72 Id. at 691-92.

73461 U.S. 95 (1983).

${ }^{74}$ In that case, the plaintiff was subjected to a stranglehold by the police, administered with such force that it rendered him unconscious and damaged his larynx, despite the fact that the situation did not justify the use of deadly force. Id. at 97-98. No injunction, however, was issued to prevent further use of strangleholds since the plaintiff could not show that he likely would suffer the same violence again, even though others might. Id. at 111 . The court justified its ruling with the rationale that "[a]bstract injury is not enough" to issue an injunction, Id. at 101.

${ }_{75}$ Harrington, supra note 58, at 439.

76 See HUMAN RIGHTS WATCH, supra note 8, at 119 (citing a report by the law firm of Piper \& Marbury, dated June 29, 1995, regarding the civilian complaint review board in Washington, D.C., citing City of Canton v. Harris, 489 U.S. 378, 389 (1990)).

${ }^{77}$ Will v. Mich. Dep't of State Police, 491 U.S. 58, 70-71 (1989). 
Constitution, plaintiffs are limited to securing equitable remedies. ${ }^{78}$

\section{Using the ADA AS AN Alternative MEANS OF PURSUING POLICE MISCONDUCT LITIGATION}

\section{A. How the ADA Works When Used Against Government Entities: A Brief Introduction}

Congress has expressed a willingness to curb unconstitutional discrimination based on race, evidenced in part by the passage of $\$ 1983 .^{79}$ It has also expressed an interest in curbing discrimination based on disabilities, as evidenced by the passage of the ADA. ${ }^{80}$ If the allegedly discriminating party, however, is a police officer or department, the protections against racial discrimination are rendered ineffective under $\S 1983$. The ADA may offer plaintiffs greater potential to prevail in police misconduct claims than $\S 1983$.

Professor James Harrington has emerged as a leader of efforts to use an ADA-oriented approach to police misconduct litigation. He emphasizes that the ADA "provides relief in a great number of situations in which $\S 1983$ does not," and in some situations bolsters the effectiveness of $\S 1983 .^{81}$ He has referred to the ADA as "the most comprehensive civil rights law passed by Congress," ${ }^{82}$ protecting people with disabilities from discrimination based on disability, perceived disability, or association with the disabled. Specifically, the ADA explains that " $[\mathrm{t}]$ he term 'disability' means, with respect to an individ-

${ }^{78}$ Harrington, supra note 58, at 439-40.

${ }^{79}$ Section 1983 states in relevant part:

Every person who, under color of any statute, ordinance, regulation, custom, or usage, of any State or Territory or the District of Columbia, subjects, or causes to be subjected, any citizen of the United States or other person within the jurisdiction thereof to the deprivation of any rights, privileges, or immunities secured by the Constitution and laws, shall be liable to the party injured in an action at law, suit in equity, or other proper proceeding for redress, except that in any action brought against a judicial officer for an act or omission taken in such officer's judicial capacity, injunctive relief shall not be granted unless a declaratory decree was violated or declaratory relief was unavailable.

42 U.S.C. $\$ 1983$ (Supp. V 1999). "Rejecting the restrictive interpretations previously made of $\$ 1983$, the Supreme Court set forth an expansive construction of that statute, emphasizing the intention of Congress to create a broad federal remedy for violations of constitutional rights." AVERY ET AL., supra note $8, \$ 1: 1$.

${ }^{80}$ See infra notes $128-31$ and accompanying text (discussing the purpose of the ADA).

Harrington, supra note 58, at 437.

${ }^{82}$ Id. 
ual-(A) a physical or mental impairment that substantially limits one or more of the major life activities of such individual; (B) a record of such an impairment; or (C) being regarded as having such an impairment." ${ }^{, 83}$ The statute also requires "reasonable modification to accommodate individuals with disabilities." ${ }^{84}$ Harrington notes that "[t]he exceptions are few and limited."

Most ADA claims are sustained under Titles I, II, and III of the Act. $^{86}$ Title I provides protection in employment situations. ${ }^{87}$ Title II ensures that government agencies are responsible for modifying their programs and premises to accommodate people with disabilities. ${ }^{88} \mathrm{Ti}-$ tle III extends the protections of Title II to cover private businesses. ${ }^{89}$ Title IV deals with accommodation as it applies to telecommunications, ${ }^{90}$ and Title $\mathrm{V}$ further enumerates miscellaneous provisions. ${ }^{91} \mathrm{Ti}-$ tles II and III "may be enforced through a private cause of action for injunctive, declaratory, and monetary relief (as well as attorney's fees, costs, and litigation expenses) or through a Department of Justice enforcement action."

The broad language of the ADA, along with the absence of any stated exceptions, has given rise to plaintiffs' attempts to apply Title II claims to areas involving law enforcement. ${ }^{93}$ Section 12132 of the ADA states that "no qualified individual with a disability shall, by reason of such disability, be excluded from participation in or be denied the benefits of the services, programs, or activities of a public entity, or be subjected to discrimination by any such entity." A4 "public entity" includes "any department, agency, special purpose district, or other instrumentality of a State or States or local government." ${ }^{95}$ The Supreme Court $^{96}$ and lower federal courts ${ }^{97}$ have explicitly acknowledged

${ }^{83} 42$ U.S.C. $\$ 12102(2)$ (1994).

${ }^{84}$ See Harrington, supra note 58, at 441 (referring to 42 U.S.C. $\$ \S 12131(2)$, $12182(2)$ (A) (ii)).

${ }^{85}$ See id. (referring to 42 U.S.C. $\$ 12182(3)$ ).

${ }^{86} I d$. at 440 .

${ }^{87} 42$ U.S.C. $\$ \S 12111-12117$.

${ }^{88} I d . \S \S 12131-12165$.

${ }^{89}$ Id. $\S \S 12181-12189$.

${ }^{90} 47$ U.S.C. $\$ 225$.

${ }^{91} 42$ U.S.C. $\$ \S 12201-12213$.

${ }^{92}$ See Harrington, supra note 58, at 441 (referring to $\$ \$ 12133,12188$ ).

${ }^{93}$ See infra notes $96-97$ (listing cases where plaintiffs brought claims against law enforcement and corrections officials under the ADA).

${ }^{94} 42$ U.S.C. $\$ 12132$.

${ }^{95} 42$ U.S.C. $\$ 12131$ (1) (B).

${ }^{96}$ See Pa. Dep't of Corr. v. Yeskey, 524 U.S. 206, 208 (1998) (involving a prison in- 
the validity of applying the ADA to actions against law enforcement agencies as well.

\section{B. What the ADA Offers over and Above Traditional Civil Rights Statutes}

While he does not consider plaintiffs of color in particular, Harrington argues that the ADA is often more useful than $\S 1983$ for police misconduct litigation generally. ${ }^{18}$ Although it is difficult to prevail even with ADA claims in many areas of the law, ${ }^{99}$ Harrington and other practitioners ${ }^{100}$ note that courts have held that the ADA constitutionally may circumvent several of the technical obstacles to secur-

mate who sued corrections officials under the ADA for discrimination due to the inmate's medical history of hypertension).

${ }^{97}$ See Hainze v. Richards, 207 F.3d 795, 799 (5th Cir. 2000) (noting that the defendant Williamson County Sheriff's Department is a public entity, and therefore is obligated to adhere to Title Il's mandates for equal protection of people with disabilities); Key v. Grayson, 179 F.3d 996, 997 (6th Cir. 1999) (involving a hearing impaired inmate who sued employees of the Michigan Department of Corrections under the ADA); Onishea v. Hopper, 171 F.3d 1289, 1292-93 (11th Cir. 1999) (involving a suit filed under the ADA by plaintiff inmates against a department of corrections for segregating the inmate population according to the results of HIV screenings); Gorman v. Bartch, 152 F.3d 907, 909 (8th Cir. 1998) (addressing a paraplegic who was injured while being transported after his arrest and filed suit under the ADA against members of the city Board of Police Commissioners, the Chief of Police, and the officer who drove the transport vehicle); Chisolm v. Manimon, 97 F. Supp. 2d 615, 622 (D.N.J. 2000) (noting that the ADA's application to public entities may apply in a prison context); Calloway v. Boro of Glassboro Dep't of Police, 89 F. Supp. 2d 543, 546 (D.N.J. 2000) (involving a deaf and functionally illiterate plaintiff who sued the police under the ADA); Higgins v. Beckworth, No. 5:00-cv-78, 2000 U.S. Dist. LEXIS 12708, at *6 (W.D. Mich. Aug. 28, 2000) (noting that the ADA applies to inmates in state prisons); Montez v. Romer, 32 F. Supp. 2d 1235, 1239 (D. Colo. 1999) (noting that the ADA contains no limitations that would prevent its application to prisons); Lewis v. Truitt, 960 F. Supp. 175, 176-77 (S.D. Ind. 1997) (applying the ADA to the arrest of a deaf man for not responding to the arresting officers, even though arresting officers knew or should have known that the man could not hear); Barber v. Guay, 910 F. Supp. 790, 802 (D. Me. 1995) (addressing a claim that plaintiff's being denied proper police protection and fair treatment during arrest due to his disability and deciding the claim is a valid cause of action under the ADA).

${ }^{98}$ See Harrington, supra note 58, at 437 ("There are five major impediments to success in typical $\$ 1983$ litigation ... . A quick overview of these immunities and practices demonstrates the pitfalls of $\S 1983$ actions, and illustrates how the ADA surmounts these roadblocks in many instances.").

${ }^{99}$ See, e.g., Susan Stefan, Delusions of Rights: Americans with Psychiatric Disabilities, Employment Discrimination and the Americans with Disabilities Act, 52 ALA. L. REV. 271, 271 (2000) ("[The] belief that Title I of the [ADA] protects an individual from employment discrimination based on psychiatric disability or perceived psychiatric disability amounts to a delusion of rights.").

${ }^{100}$ See Frishberg, supra note 63 (identifying the ADA standard of respondeat superior as an advantage over $\$ 1983$ Monell liability). 
ing remedies for abuse at the hands of police officers mentioned above, while civil rights statutes do not.

\section{Interlocutory Appeal and Immunity}

Because ADA actions lie against government entities rather than the individuals employed by them, the problems of qualified immunity, municipal immunity, and interlocutory appeal ${ }^{101}$ do not come into play in ADA litigation. ${ }^{102}$ Although the Supreme Court recently struck down the ability of the ADA to abrogate the Eleventh Amendment sovereign immunity of states, ${ }^{103}$ that decision has no bearing on substate government entities, such as municipalities or counties. ${ }^{104}$

101 See supra Part I.B (discussing these problems).

${ }^{102}$ Harrington, supra note 58, at 442.

${ }^{103}$ See Bd. of Trs. of the Univ. of Ala. v. Garrett, 531 U.S. 356, 368 (2001) (stating that " $[t]$ he legislative record of the ADA ... fails to show that Congress . . . identif[ied] a pattern of irrational state discrimination in employment against the disabled," and thus did not support abrogation of the states' Eleventh Amendment immunity from suits for money damages under Title I of the ADA). Despite Garrett, a statute created for the purpose of curbing police misconduct might still be salvaged from similar sovereign immunity impediments. A pattern of irrational state discrimination with respect to police misconduct arguably could be established for some states. See, e.g., INTERIM REPORT, supra note 8, at 4 (providing an example of a situation in which the state's own attorney general admitted that the state troopers treated minority motorists differently than white motorists). Even if a record were established, the Garrett Court still feared that "the rights and remedies created by the ADA against the States would raise ... concerns as to congruence and proportionality." 531 U.S. at 372. Specifically, the Court held that the accommodation duty under the ADA exceeded what was constitutionally required by making it the employer's duty to prove it would suffer hardship from accommodation. See id. ("For example ... it would be entirely rational (and therefore constitutional) for a state employer to conserve scarce financial resources by hiring employees who are able to use existing facilities...."). Therefore, the Court held that the Constitution requires that the complaining party negate the reasonable basis for the employer's decision. Id. For the purposes of constructing a police misconduct statute, one could infer from the Court's reasoning that if a statute were to require a plaintiff to negate the reasonableness of a police officer's decision to act in a certain manner (assuming for the moment that a plaintiff could do so), such a statute would not similarly exceed the Constitution's requirements. If one could make the case that it would not be "entirely rational" for police to engage in misconduct against people of color more than they do against whites, then the reasoning in Garrett would not similarly apply to a police misconduct statute for people of color.

Finally, the Court specified that " $[t]$ he ultimate guarantee of the Eleventh Amendment is that nonconsenting States may not be sued by private individuals in federal court." $I d$. at 363 (emphasis added). Though it is unlikely, if a state's legislature voted to adopt a statute abrogating that state's immunity (based on its own failure to correct the problem of police misconduct), it could conceivably do so.

${ }^{104}$ See id. at 369 ("[T]he Eleventh Amendment does not extend its immunity to units of local government."). 


\section{Respondeat Superior}

The ADA does not require proof of intentional discrimination if there is a showing of a practice that in fact discriminates. ${ }^{105}$ Thus, actions of a government employee-whether they are explicitly discriminatory or have a discriminatory effect-are grounds for liability against the government entity. This is the equivalent of respondeat superior liability. By contrast, Monell v. New York City Department of Social Services $^{106}$ holds that a municipality is not vicariously liable for the acts of its employees in civil rights actions. ${ }^{107}$ To impose municipal liability under Monell, the plaintiff must prove that a municipal policy

105 See 42 U.S.C. $\$ 12112$ (b) (1) (2001) (noting that the term "discriminate" includes "limiting, segregating, or classifying a job applicant or employee in a way that adversely affects the opportunities or status of such applicant or employee because of the disability of such applicant or employee"); 42 U.S.C. $\$ 12112$ (b) (3) (A) (noting that "discriminate" includes using standards, criteria, or methods of administration "that have the effect of discrimination on the basis of disability"). Commentors also have weighed in. Professor Jacobi observed:

After reciting the legislative history of the Rehabilitation Act describing Congress's appreciation of the degree of intentional and unintentional discrimination faced by the disabled ... the Court stated, "These statements would ring hollow if the resulting legislation could not rectify the harms resulting from action that discriminated by effect as well as design."

John V. Jacobi, Fakers, Nuts, and Federalism: Common Law in the Shadow of the ADA, 33 U.C. DAVIS L. REV. 95, 127 n.192 (1999) (quoting Alexander v. Choate, 469 U.S. 287, 297 (1985)); see also Diane L. Kimberlin \& Linda Ottinger Headley, ADA Overview and Update: What Has the Supreme Court Done to Disability Law?, 19 REV. LITIG. 579, 605 (2000) ("Employers may not use standards, criteria, or methods of administration that have the effect of discriminating on the basis of disability .... Thus, like many other anti-discrimination statutes, the ADA prohibits both intentional discrimination and unintentional discrimination ...."). In addition, the Supreme Court in Franklin $v$. Gwinnett County Public Schools, 503 U.S. 60 (1992),

strongly heralded that, absent express congressional direction to the contrary, the federal courts have wide latitude to award any appropriate relief. Contrary to many recent federal court decisions requiring "intentional discrimination," Supreme Court precedent establishes that such damages are inappropriate under Title II only if the public entity does not have notice of the potential for liability.

Leonard J. Augustine, Jr., Disabling the Relationship Between Intentional Discrimination and Compensatory Damages Under Title II of the Americans with Disabilities Act, 66 GEO. WASH. L. REV. 592, 622 (1998). But see id. at 593 (noting that the United States District Court for the District of Arizona ruled in Ferguson v. City of Phoenix, No. CIV-95-260-PHX-RCB, slip op. at 6 (D. Ariz. Oct. 18, 1996), that the plaintiff "needed to prove that the city 'intentionally discriminated' to recover compensatory damages").

${ }_{106} 436$ U.S. 658 (1978).

${ }^{107}$ See id. at 691 ("[A] municipality cannot be held liable under $\S 1983$ on a respondeat superior theory."). The case, however, also held that a municipality is not immune from liability for engaging in its own unconstitutional policies. Id. 
or custom exists that caused the constitutional violation at issue. ${ }^{108}$ Courts have also required proof of causation and culpability, such that the policy is the "moving force" behind the violation and there is an "affirmative link" between the policy and the violation. ${ }^{109}$ Monell liability is difficult for plaintiffs to prove. ${ }^{110}$ The actions of rogue officers, or undisciplined police forces as a whole, therefore remain unaccounted for by local police departments in $\S 1983$ suits, slipping through the cracks one incident at a time.

\section{Police Self-Evaluation and Modification}

The ADA has given rise to Department of Justice regulations that implement the ADA's requirement that government entities conduct self-evaluations of their services for persons with disabilities. ${ }^{111}$ Courts have further held that inadequate government appropriations and lack of funds do not justify a government agency's failure to conduct a thorough self-evaluation and to modify its program." "When appropriate training and policies are lacking," notes Harrington, "a creative plaintiff can use the requirement of self-evaluation and modification to push for better training programs and proper policies."113 ADA beneficiaries, therefore, are entitled to declaratory judgment regarding a government entity's failure to evaluate itself effectively, and to injunctions requiring that appropriate modifications be made. ${ }^{114}$

\section{Cruel and Unusual Conditions of Confinement}

Another area where the ADA may operate more effectively than $\S 1983$ is with respect to confinement conditions in prisons and jails. The Supreme Court has explicitly extended the ADA's purview to cover state corrections facilities. ${ }^{115}$ While federal courts hearing

\footnotetext{
108 AVERY ET AL., supra note 8, $\$ 4: 15$.

${ }^{109}$ Id. (quoting City of Oklahoma v. Tuttle, 471 U.S. 808, 823 (1985), and Polk County v. Dodson, 454 U.S. 312, 326 (1981)).

${ }^{10}$ See id. $\$ 4: 16$ (noting that "one may still expect both factual and legal issues to be hotly contested where municipal liability claims are made" and that "[i]n general the area is not an easy one for plaintiffs").

11128 C.F.R. $\$ 35.105$ (a)-(b) (2001), cited in Harrington, supra note 58, at 445.

${ }^{112}$ L.C. by Zimring v. Olmstead, 138 F.3d 893, 904-05 (11th Cir. 1998), affd in part, vacated in part, and remanded by 527 U.S. 581 (1999); Harrington, supra note 58, at 446 (citing Alabama Nursing Home Ass'n v. Harris, 617 F.2d 388 (5th Cir. 1980)).

${ }^{113}$ Harrington, supra note 58, at 446.

114 Id.

${ }^{115}$ Pa. Dep't of Corr. v. Yeskey, 524 U.S. 206, 210 (1998).
} 
$\S 1983$ cases alleging "cruel and unusual" conditions in prisons accord "enormous deference" cials to make a reasonable accommodation to the needs of a prisoner with a disability." ${ }^{118}$ For example, suicide while in confinement may be treated differently under the ADA than under $\$ 1983 .{ }^{1 "}$ Unlike $\S 1983$, the ADA establishes an affirmative duty to accommodate persons with mental illness and suicidal tendencies, putting the onus on prison officials to learn affirmatively to act in an appropriate manner with the prisoners. ${ }^{120}$ Furthermore, Title III of the ADA applies to private prisons and jails, where $\S 1983$ does not apply. ${ }^{121}$

\section{Litigation Expenses}

ADA actions permit "a potentially broad recovery of a successful attorney's out-of-pocket expenses as well as attorney's fees and

${ }^{116}$ Harrington, supra note 58 , at 447.

117 See Farmer v. Brennan, 511 U.S. 825, 837 (1994) (requiring that prison officials who recklessly disregard a substantial risk to an inmate's health or safety be liable under the Eighth Amendment).

${ }_{118}$ Harrington, supra note 58 , at 447 . Harrington adds:

Because the ADA places an affirmative burden on the officials, it may sometimes be easier for a prisoner with a disability to prevail under the ADA than under $\$ 1983$. In some instances, a court may even look to the ADA as a way of informing 8th or 14th Amendment standards. This latter approach might offer great promise in jail conditions litigation by prisoners with disabilities. Id. at 447-48 (citation omitted).

${ }_{119}$ See, e.g., Flores v. County of Hardeman, 124 F.3d 736, 738-39 (5th Cir. 1997) (analyzing issues of liability under $\S 1983$ for an inmate suicide). To hold a municipality accountable under $\$ 1983$ for an "episodic act or omission" leading to suicide, the plaintiff must show that the municipal employee violated clearly established constitutional rights of the inmate with subjective deliberate indifference, and that the violation resulted from a municipal policy or custom adopted or maintained with objective deliberate indifference. Id. at 738 (citing Farmer, 511 U.S. at 834); see also, e.g., Hare v. City of Corinth, 135 F.3d 320, 328 n.1 (5th Cir. 1998) (rendering judgment in favor of officers who knew and believed the decedent female prisoner was suicidal, but did not remove a blanket from her cell because they believed she was not strong enough to hang herself, and who only checked her cell hourly); id. (discussing the trustee who discovered her hanging in the cell and left her hanging, although it was determined that she might have survived with emergency treatment). As such, "the less officials know about appropriate conduct with respect to potentially suicidal inmates, the less objective legal responsibility they have," which diminishes motivation to "cajole jail officials into implementing appropriate training." Harrington, supra note 58, at 450.

${ }^{120}$ Harrington, supra note 58 , at 450 . Harrington suggests that Title III standards may "help define the parameters of reasonable care and negligence in cases involving prisoners with disabilities." Id. at 452.

${ }^{121}$ See, e.g., Martin v. Corr. Corp. of Am., No. 3-97-CV-2895-BD (N.D. Tex. 1997) (settling for monetary damages in a suicide case alleging inappropriate self-medication for a mentally ill and suicidal inmate in a private correctional facility). 
costs." Creating an incentive for lawyers to accept ADA cases as a matter of national policy, Congress designed the ADA to facilitate the plaintiff's attorney's recovery of the expenses of ADA cases. ${ }^{123}$ While the civil rights statutes, under 42 U.S.C. $\$ 1988$, provide for attorney's fees, costs, and expert fees, $\S 1988$ (b) and (c) does not allow fees against a judicial officer unless the officer acted "clearly in excess" of the officer's jurisdiction. ${ }^{124}$ By contrast, the ADA does not protect a judicial officer from fee collection. ${ }^{125}$

\section{THE CURRENT INTERPRETATION OF THE ADA IS BIASED AGAINST PEOPLE OF COLOR}

The ADA therefore offers a viable alternative to $\S 1983$ causes of action on behalf of victims of police misconduct who, due to disabilities, may be prone to have unique interactions with law enforcement officials, and who must be provided special accommodation. ${ }^{126}$ Indeed, "[t]he areas in which ADA seems to be most applicable," Harrington asserts, "involve accommodation of physical disabilities, appropriate use of force, mental illness calls, and the need for interpreting." 127

Congress, relying on census data and other studies, decided that individuals with disabilities "are a discrete and insular minority"128 who, "as a group, occupy an inferior status in our society, and are se-

${ }^{122}$ Harrington, supra note 58, at 461 (citing 42 U.S.C. $\$ 12205$ (1994)). The statute provides:

In any action or administrative proceeding commenced pursuant to this chapter, the court or agency, in its discretion, may allow the prevailing party, other than the United States, a reasonable attorney's fee, including litigation expenses, and costs, and the United States shall be liable for the foregoing the same as a private individual.

42 U.S.C. $\$ 12205$ (1994).

${ }^{123}$ See Harrington, supra note 58, at 462-63 ("Congress passed $\$ 12205$ of the ADA as an incentive for private attorneys to take ADA cases and thus aid in the enforcement of the ADA as a matter of national policy.").

${ }^{124} I d$. at 461 .

${ }^{125} \mathrm{Id}$.

${ }^{126}$ See, for example, Lewis v. Truitt, 960 F. Supp. 175, 177 (S.D. Ind. 1997), in which a deaf grandfather filed suit under the ADA after he was arrested for conduct that occurred when officers arrived to transfer custody of his granddaughter. The court held that the grandfather had a right to be informed of the officers' authority, and that the grandfather could recover on his claim if the officers knew he was deaf, failed to try to communicate with him, and then arrested him for not responding appropriately. Id.

\footnotetext{
${ }^{127}$ Harrington, supra note 58 , at 453.

12842 U.S.C. $\$ 12101$ (a) (7) (1994)
} 
verely disadvantaged socially, vocationally, economically, and educationally." ${ }^{29}$ Congress's stated purpose in enacting the ADA was "to provide a clear and comprehensive national mandate for the elimination of discrimination against individuals with disabilities," invoke the sweep of congressional authority ... in order to address the major areas of discrimination faced day-to-day by people with disabilities." ${ }^{\prime 11}$

The Supreme Court agrees with Congress's assessment. It "has recognized that the ADA contains an integration mandate in addition to its non-discrimination and accommodation mandates." ${ }^{\text {192 }}$ This integration regulation requires that a "public entity must assist persons with disabilities as much as possible in being a full member of society" ${ }^{\text {"193 }}$ by administering programs "in the most integrated setting appropriate to the needs of qualified individuals with disabilities." ${ }^{134}$ The Eighth Circuit, echoing the Supreme Court, pronounced that the regulatory obligation to modify policies and practices requires law enforcement entities to change policies that result in discriminatory arrests or abuse of people with disabilities. ${ }^{135}$ Plaintiff responses to police that otherwise might be considered atypical or suspicious may even be recognized as legitimate under the $\mathrm{ADA} .^{136}$

The courts have interpreted the term "disability" as it is described in the $\mathrm{ADA}^{137}$ to include various physical conditions, determined on a case-by-case basis, ${ }^{198}$ such as cystic fibrosis, ${ }^{139}$ asthma, ${ }^{140}$ diabetes, ${ }^{141}$ epi-

Id. $\$ 12101(\mathrm{a})(6)$

${ }^{130}$ Id. $\$ 12101(\mathrm{~b})(1)$.

${ }^{191}$ Id. $\$ 12101$ (b) (4).

${ }^{132}$ Harrington, supra note 58 , at 460

${ }^{133}$ Id.

${ }_{134}$ Id. (quoting Olmstead v. L.C., 527 U.S. 581, 582 (1999)).

${ }^{135}$ Harrington, supra note 58, at 454 (citing Gorman v. Bartch, 152 F.3d 907 (8th Cir. 1998)).

${ }^{196}$ See supra notes 15, 126 (discussing one example of such a case, Lewis $v$. Truitt, 960 F. Supp. 175 (S.D. Ind. 1997))

${ }_{138}^{137}$ See supra Part II.A (discussing the ADA in relation to government entities).

${ }^{138}$ See Davoll v. Webb, 160 F.R.D. 142, 145 (D. Colo. 1995) (holding that the determination of whether an individual has disabilities under the ADA must be "decided on a case-by-case basis"), aff d, 194 F.3d 1116 (10th Cir. 1999).

${ }^{199}$ See Emery v. Caravan of Dreams, 879 F. Supp. 640, 642 (N.D. Tex. 1995) (holding that the plaintiff was "substantially impaired in the major life function of breathing"), affd, 85 F.3d 622 (5th Cir. 1996).

${ }^{140}$ See Valentine v. Am. Home Shield Corp., 939 F. Supp. 1376, 1292-93 (N.D. Iowa 1996) (" $[\mathrm{O}] \mathrm{n}$ this record ... it is undisputed that [the plaintiff's] asthma is a disability within the meaning of the ADA.").

${ }^{141}$ See Sarsycki v. United Parcel Serv., 862 F. Supp. 336, 340 (W.D. Okla. 1996) 
rely on the Diagnostic and Statistical Manual of Mental Disorders (DSM) of the American Psychiatric Association for definitions of PTSD $^{150}$ and other similar stress disorders, often in cases involving alleged violations of the ADA. ${ }^{151}$

The list of PTSD-causing stressors enumerated in the DSM appears to be ambiguously conceived, however, because stressors not mentioned produce symptoms that also would satisfy the DSM's own criteria for a diagnosis of PTSD. ${ }^{152}$ Indeed, there is evidence that the DSM definition of PTSD adopted by the courts may be arbitrarily too narrow. ${ }^{153}$ Some clinicians have grown suspicious of the validity of the

\footnotetext{
${ }^{150}$ The DSM-IV states:
}

The essential feature of Posttraumatic Stress Disorder is the development of characteristic symptoms following exposure to an extreme traumatic stressor involving direct personal experience of an event that involves actual or threatened death or serious injury, or other threat to one's physical integrity; or witnessing an event that involves death, injury, or a threat to the physical integrity of another person; or learning about unexpected or violent death, serious harm, or threat of death or injury experienced by a family member or other close associate.

DSM-IV, supra note 149 , at 424 . The symptoms recognized by the DSM-IV as indicative of PTSD, when two or more of them are present, are: (1) difficulty sleeping or staying asleep; (2) irritability or outbursts of anger; (3) difficulty concentrating; (4) hypervigilance; and (5) exaggerated startle response. Id. at 428.

${ }^{151}$ See Skretvedt v. E.I. DuPont de Nemours \& Co., 268 F.3d 167, 181 (3d Cir. 2001) (relying on the DSM-IV's definition of what constitutes an "adjustment disorder" in a case where plaintiff filed suit alleging violation of the ADA based on such disorder); EEOC v. Aramark Corp., 208 F.3d 266, 272 (D.C. Cir. 2000) (refusing to find defendant's long-term disability benefit plan, which specifies limits of benefits to persons suffering mental or emotional distress as defined in the most current edition of the DSM, to be in violation of the ADA); Jackson v. Chubb Corp., 193 F.R.D. 216, 227 (D.N.J. 2000) (acknowledging the validity of plaintiff's submission of a diagnosis of PTSD as defined by the DSM-IV, and requiring that defendant be given the opportunity to verify that diagnosis); Zale v. Sikorsky Aircraft Corp., No. 3:97CV00125(JBA), 2000 WL 306943 , at *1 \& n.1 (D. Conn. Feb. 7, 2000) (reviewing plaintiff's submission of a definition of PTSD as provided in various editions of the DSM); Calovine v. City of Bridgeport, No. 3:94CV00379(WWE), 1998 WL 171443, at*8 (D. Conn. Jan. 27, 1998) (finding that a doctor's testimony regarding PTSD based on the DSM-IV was proper, over defendant's objections); In re Matthew S., 1999 WL 545359, at *6-7 nn.8-9 (Conn. Super. Ct. July 16, 1999) (considering counsel's reliance on the DSM-IV's definition of personality disorder). But see Williams v. N.Y. State Dep't of Labor, No. 98 Civ. 3816(RMB), 2000 WL 33175735, at *9 (S.D.N.Y. May 25, 2000) (noting that plaintiff offered "little evidence that her (stress-related) mental condition(s) constitute "impairment' under the ADA," even though plaintiff submitted that a social worker diagnosed her with Generalized Anxiety Disorder as defined by the DSM-IV).

${ }^{152}$ Kirtland C. Peterson ET al., POSt-Traumatic Stress Disorder: A CliniCian's GUIDE 135 (1991) (noting that diagnoses of PTSD are denied in "some patients present with sufficiently intense symptoms, but without the necessary stressor (these are referred to as 'idiosyncratic' disorders)").

${ }^{153}$ Recently, some doctors have questioned "whether DSM-III, DSM-IIIR, or DSM- 
lepsy, ${ }^{142}$ and being HIV-positive. ${ }^{143}$ Mental and emotional conditions also have been held to be within the rubric of the ADA's protection. ${ }^{144}$ For instance, individuals with learning disabilities, ${ }^{145}$ depressive disorders, ${ }^{146}$ and anxiety and stress disorders ${ }^{147}$ may be regarded as having disabilities.

PTSD is one mental disability explicitly acknowledged in caselaw as meriting protection under the $\mathrm{ADA} .{ }^{148}$ The National Institute of Mental Health has described PTSD as an "extremely disabling condition" that can occur "after exposure to a terrifying event or ordeal in which grave physical harm occurred or was threatened." ${ }^{\prime 19}$ The ADA recognizes the reality and the seriousness of PTSD, and it recognizes that the condition can be created by environmental stressors. Courts

(holding that an individual had a disability since without medication he would be unable to perform major life activities).

${ }_{142}$ See EEOC v. Kinney Shoe Corp., 917 F. Supp. 419, 425 (W.D. Va. 1996) (holding that an individual prone to tonic-clone seizures that temporarily rendered him unconscious had a disability), affd sub nom. Martinson v. Kinney Shoe Corp., 104 F.3d 683 (4th Cir. 1996).

${ }^{143}$ See D.B. v. Bloom, 896 F. Supp. 166, 170 n.4 (D.N.J. 1995) (concluding that plaintiff had a disability by virtue of HIV status and citing 28 C.F.R. $\$ 36.104(l)$ (iii)).

${ }^{144}$ See Lee v. Los Angeles, 250 F.3d 668, 691 (9th Cir. 2001) (noting that mental health services and other activities undertaken by law enforcement are services, programs, or activities of a public entity within the meaning of the ADA); Applicants v. Tex. Bd. of Law Exam'rs, 4 Am. Disabilities Cas. (BNA) 165, 170 (W.D. Tex. 1994) (holding that persons who are not currently impaired, but who have a history of mental illness or emotional disorder, may fit within the statutory definition of having a disability).

${ }^{145}$ See Pottgen v. Mo. State High Sch. Activities Ass'n, 857 F. Supp. 654, 662 (E.D. Mo. 1994) (holding that if an individual is diagnosed as having a learning disability, she has a disability within the meaning of the ADA).

${ }^{146}$ See Pritchard v. S. Co. Servs., 92 F.3d 1130, 1133 (11th Cir. 1996) (noting that depression by itself does not constitute a disability unless the person can show that in her particular case, a jury could find that depression did constitute a disability).

${ }^{47}$ See Groncki v. Stewart's Ice Cream Co., No. 98-7263, 1999 U.S. App. LEXIS 22310 , at $* 4$ (2d Cir. Feb. 10, 1999) (deciding that a plaintiff suffering from PTSD was a qualified individual with a disability and offered evidence sufficient to overcome defendant's motion for summary judgment).

${ }^{148}$ Id.; see also DISABILITY RIGHTS SECTION, U.S. DEP'T OF JUSTICE, ENFORCING THE ADA: A STATUS REPORT FROM THE DEPARTMENT OF JUSTICE (Apr.June 1997) (“A national licensing board [in the Western District of Michigan] agreed to make testing accommodations for a student with PTSD, including placing the student in a separate room, allowing extra time to complete the exam, and providing a break between each portion of the exam."), http://www.usdoj.gov:80/crt/ada/aprjun97.pdf.

${ }^{149}$ NAT'L InST. OF MENTal Health, Facts About Post-Traumatic Stress DisORDER (Oct. 2001), available at http://www.nimh.nih.gov/anxiety/ptsdfacts.cfm; see also AM. Psychiatric Ass'N, Diagnostic and Statistical ManUal of MENTAL DISORDERS 424 (4th ed. 1994) [hereinafter DSM-IV] (discussing the essential features of PTSD). 
current definition of PTSD and its "insistence on a major external threat [that] is too restrictive because any stressor is potentially traumatogenic," arguing that this results in significant underdiagnosing: of PTSD. ${ }^{154}$

Some evidence suggests that the underdiagnosed population is disproportionately represented by people of color: stress-inducing situations suffered by whites as well as by people of color are included under the $\mathrm{ADA},{ }^{155}$ while similar conditions suffered more often by people of color alone are not included. For instance, clinicians have suggested that exposure to physical force and display of weapons, ${ }^{156}$ witnessing abusive violence, ${ }^{157}$ suffering from substance abuse, ${ }_{158}^{150}$ residing in socioeconomically depressed inner-city neighborhoods, ${ }^{159}$ being subjected to police misconduct, ${ }^{160}$ and being homeless ${ }^{161}$ may all be

IV provides an adequate description of the psychological consequences of more ordinary stressors or the less severe reactions to extreme stressors." Glenn Craig Davis \& Naomi Breslau, Post-Traumatic Stress Disorder in Victims of Civilian Trauma and Criminal Violence, 17 PSYCHIATRIC ClINICS N. AM. 289, 289 (1994). Others have noted that "because in the pathologic (stressful) reaction to a traumatic event, the boundary between the mentally healthy and the mentally ill is obscured, the subject is difficult for clinicians to consider." Stephen M. Sonnenberg, Victims of Violence and Post-Traumatic Stress Disorder, 11 PSYChiatric Clinics N. Am. 581, 581 (1988).

${ }_{154}$ Davis \& Breslau, supra note 153, at 296. But see PETERSON ET AL., supra note 152, at 134 (noting a "tendency among some clinicians not to maintain strict adherence to the criteria for PTSD as outlined in the DSM-III" because it is overinclusive).

${ }_{155}$ The DSM-IV explicitly enumerates the events acknowledged to produce the symptoms of PTSD. Military combat, violent personal assault, being taken hostage, terrorist attack, torture, incarceration as a prisoner of war or in a concentration camp, natural or manmade disasters, auto accidents, or being diagnosed with a lifethreatening illness are the events that are clinically recognized as rising to the level of trauma needed to support a diagnosis of PTSD. DSM-IV, supra note 149, at 424. Each of these are traumas to which whites as well as people of color have been exposed, as compared to those to which people of color are disproportionately exposed. See infra notes 156-75 (distinguishing between stressors to which whites and people of color are generally exposed).

${ }^{150}$ Davis \& Breslau, supra note 153, at 297.

${ }^{157}$ I. LiSa MCCANN \& LaUrie ANNE PEARlman, PSYChOlogical Trauma and THE ADULT SURVIVOR: THEORY, THERAPY, AND TRANSFORMATION 110 (1990).

${ }^{158}$ But see PETERSON ET AL., supra note 152, at 38 (stating that "[w] hereas substance abuse was considered possible in the DSM-III description of PTSD, the DSM-III$R$ description indicates that psychoactive substance use disorders are common complications of the disorder," and were thus omitted from the list of diagnostic stressors).

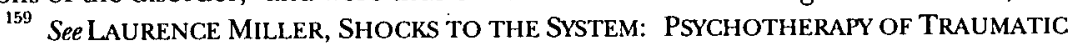
DISABILITY SYNDROMES 160-61 (1998) (claiming that "residents of crime-ridden and socioeconomically depressed inner-city neighborhoods" have exhibited "classic signs and symptoms of PTSD").

${ }^{160}$ See infra notes $177-88$ and accompanying text (examining stressors that are commonly associated with police misconduct). 
correlated with mental disabilities. In the United States, people of color are, or have been, more frequently exposed to these types of environmental stressors, including military combat in the Vietnam War, ${ }^{162}$ violent personal assault ${ }^{163}$ (including sexual assault, ${ }^{164}$ physical attack, robbery, ${ }^{165}$ and mugging), exposure to low-income neighborhoods $^{166}$ and public schools (which are often subject to higher incidences of such crimes), and police misconduct. ${ }^{167}$ In addition to being disproportionately exposed to PTSD-inducing stressors, some people of color may face challenges in their efforts to obtain treatment $^{168}$ and in recovery ${ }^{169}$ that are not faced by white individuals offi-

161 See I. Lyall et al., Incidence of Persons with a Learning Disability Detained in Police Custody, 35 MED. SCI. \& L. 61, 70 (1995) (noting that "epidemiological studies have demonstrated that people with mild learning disabilities may live in deprived settings and ... psychiatric disorder [s] are increased compared to the general population").

${ }^{162}$ Military combat is one of the enumerated PTSD-inducing stressors in the DSM-

IV. Supra note 149, at 424. The Vietnam War in particular has been recognized as an especially pernicious source of PTSD symptoms. Researchers found:

Higher symptom levels in black subjects were accounted for by higher levels of stressors during their war experience, with more intense combat experiences.

There was no requirement to postulate a racial sensitivity to PTSD. Rather, this study suggested that black soldiers saw or perceived more stressful combat exposure than white soldiers.

L. Stephen O'Brien, Traumatic Events and Mental Health 61-62 (1998). And while discussion of the Vietnam War usually focuses on United States veterans, a significant population of Vietnamese Americans now live in the United States, many of whom were soldiers for the Viet Minh. Even those Vietnamese Americans who were not soldiers were exposed to many of the same stressors as U.S. veterans were during the war, and therefore they also may be at risk of suffering from PTSD.

${ }^{163}$ People of color are disproportionately exposed to these stressors. See U.S. CENSUS BUREAU, STATISTICAL ABSTRACTS OF THE UNITED STATES 220 (119th ed. 1999) (documenting that in 1997, there were 49.0 victims of violent crime per 1000 persons among blacks, 43.1 among Hispanics, and 38.3 among whites); MILLER, supra note 159, at 160-61 (noting that, in one study, "almost half of th [e] sample of young inner-city adults reported experiencing potentially traumatic events and about a quarter of them developed full-blown PTSD").

${ }^{164}$ See Wriggins, supra note 8 , at $122 \mathrm{n} .118$ ("Recent data from random citizen interviews suggest that Black women are much more likely to be victims of illegal rape than are white women.").

${ }^{165}$ COLE, supra note 6, at 5 ("African Americans are victimized by robbery at a rate 150 percent higher than whites.”).

${ }^{160}$ U.S. CENSUS BUREAU, supra note 163, at 220 (indicating that per 1000 persons, those living in households with incomes of less than $\$ 7,000$ had a crime index of 71 , households with an income of anywhere from $\$ 7,500$ to $\$ 14,999$ had an index of 51.2 , and households with an income greater than or equal to $\$ 75,000$ had an index of 30.7).

${ }^{167}$ See supra note 8 and accompanying text (providing an overview of the relationship between race and police brutality).

${ }^{168}$ See SANDra L. BroWN, CoUNSEling Victims of Violence 79 (1991) ("For in- 


\section{cially diagnosed with PTSD.}

Additionally, while incarceration in prisoner of war or concentration camps is considered traumatic, incarceration in penal institutions is not. The latter condition applies to a disproportionate number of people of color, while the former two categories are represented mostly by whites. None of these stressors that disproportionately affect people of color have been enumerated explicitly in the DSM- $N$ as supporting a diagnosis of PTSD. ${ }^{170}$

Other stressors that are overlooked in the clinical list of stressors are exposure to "hate crimes"171 directed at people of color and per-

stance, ethnic groups face a number of problems in reporting abuse and obtaining services. For some, their communication in English is so poor that they are unable to make their needs known to authorities or counselors."). Lack of insurance may also hamper access to recovery. Id. at 83 . In addition, one clinician noted that "[a]' major problem in beginning the counseling process with ethnic minority clients is that cultural differences are still so confusing to them and they may not understand our programs, theories, or therapies. Likewise, counselors are often unaware of clients' cultural family dynamics or strong sexist beliefs or roles." Id. at 81. Recognition of cultural chasms between client and practitioner need not be couched in such patronizing terms, and arguably the more forceful portrait of this obstacle to adequate treatment is provided by consideration of the overwhelming domination of the psychiatric profession by white practitioners. Some doctors have done their best to emphasize that

racism pervades and complicates the psychological issues experienced by members of both the majority and minority cultures.... [A] racist society ... can lead to the development of disturbed schemas about trust and safety which impede the growth of a therapeutic relationship, particularly between client and therapist of different races. Therapists must be aware of their own stereotypes about members of different racial groups in order to avoid retraumatizing clients ....

MCCANN \& PEARLMAN, supra note 157, at 117. It is further noted that "[c]linicians must understand something about the historical and cultural context [of the patient's trauma] if they are going to work effectively with these populations and understand the profound past and present impact of these events on the client's life." Id. at 114.

${ }^{169}$ Even in the hands of culturally nuanced practitioners from different ethnic groups, the recovery of people of color who suffer from PTSD or PTSD-related disorders may be impeded: Although "PTSD bypasses cultural boundaries.... [studies] reveal that counseling the ethnically different client may be similar in terms of PTSD reactions but very different in terms of social systems support and other cultural aspects that influence recovery." BROWN, supra note 168 , at 79.

${ }^{170}$ See DSM-IV, supra note 149, at 424 (listing stressors that lead to PTSD, but not including these factors that are more likely to be experienced by people of color).

${ }^{171}$ The term "hate crime" here refers to crimes directed at members of socially subordinate groups that are motivated by the victims' membership in such groups. Some commentators, however, prefer to use other terms. See Darren Lenard Hutchinson, "Gay Rights" for "Gay Whites"?: Race, Sexual ldentity, and Equal Protection Discourse, 85 CORNELL L. REv. 1358, 1374 n.81 (2000) ("Because terms such as "hate crimes' or 'bias crimes' distort the systematic, structural, and political dimensions of acts of violence against members of socially subordinate groups, I refer to such crimes 
petual exposure to racial animus in general. For instance, while Holocaust victims are explicitly recognized as likely candidates for PTSD, victims of other hate crimes are not. ${ }^{172}$ Similarly, violent personal assault of an indiscriminate nature is mentioned in the $D S M$, but racially motivated attacks are not, ${ }^{173}$ despite indications that PTSD reactions may be similar. ${ }^{174}$ This further suggests that the clinical definition of PTSD is underinclusive, narrowly defined in a manner that is disproportionately beneficial to whites.

The current interpretation of the ADA thus fosters an implication that conduct associated with adverse reactions to police is innate to people of color. ${ }^{176}$ The reactions of victims of color to police are not recognized as rational behavior, as manifestations of a normal psychiatric coping mechanism, or as behavior justified by being attributable to a clinically recognized disability. Similar reactions induced by stressors to which whites are exposed, meanwhile, are attributed to PTSD. The reactions of whites are thereby neatly explained, while the reactions of people of color hang precipitously unassociated with any such legitimizing disability.

Dismissal of the experience of victims of color, by ignoring the external stressors to which they are more likely exposed, is particularly

\footnotetext{
as acts of 'oppressive violence.'").

${ }^{172}$ DSM-IV, supra note 149 , at 424.

${ }^{178}$ Id.

${ }^{174}$ BROWN, supra note 168 , at 79.

${ }^{175}$ This is not to say that the enumerated and nonenumerated stressors are expected to produce identical symptoms. When PTSD has been studied in cross-cultural contexts, researchers have pointed out that "it is known that traumatic reactions take somewhat different forms or involve somewhat different patterns of thought in different cultural groups." Sonnenberg, supra note 153, at 587. For instance, correlations have been noted between "different varieties of potential trauma" and "the incidence of PTSD in different social groups." Id. at 584. The point is that the trauma is similar in degree, not in kind, among those exposed to stressors to which whites are more often subject and those exposed to stressors to which people of color are more often subject, and that the DSM's standard for diagnosis only recognizes the "white" kinds of stressors.

${ }^{176}$ While eugenics has been debunked forcefully enough in recent years to discourage most clinicians from relying on it to advance the erroneous correlations it engenders, Richard J. Herrnstein and Charles Murray's thoroughly discredited book, The Bell Curve, stands as a testament that such efforts are not likely to cease anytime soon. See Richard J. Herrnstein \& Charles Murray, The Bell CuRve: InTElligence and CLASS STRUCTURE IN AMERICAN LIFE 317-40 (1994) (arguing that there is a causal relation between intelligence and race). But see STEPHEN JAY GOULD, THE MiSMEASURE OF MAN 367-90 (1996) (specifically critiquing The Bell Curve). Furthermore, popular understanding of such a misinformed correlation may exacerbate already disdainful stereotypes associated with people of color.
} 
inappropriate in the context of police misconduct. Some suggest that stressors associated with police misconduct, such as sudden injury, ${ }^{177}$ witnessing injury, ${ }^{178}$ assault, ${ }^{179}$ threat to life, ${ }^{180}$ narrow escape, ${ }^{181}$ motor vehicle accidents, ${ }^{182}$ physical force, ${ }^{183}$ display of weapons, ${ }^{184}$ and victim injury $^{185}$ do in fact exacerbate PTSD. Others note that police officers incite behavior that can be, and often is, interpreted as symptomatic of various maladies, including such "odd" behavior as flight. ${ }^{186}$ There

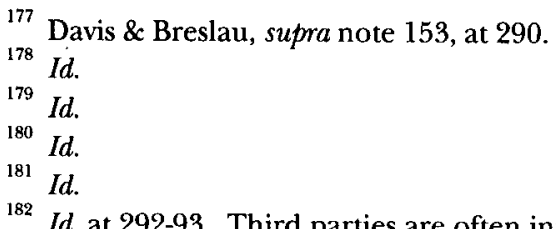

182 Id. at 292-93. Third parties are often injured by "hot-pursuit" police chases. See Geoffrey P. Albert \& Roger G. Dunham, Policing Hot Pursuits: The Discovery of Aleatory Elements, 80 J. CRIM. L. \& CRIMINOLOGY 521, 528 (1989) (noting that, for instance, a 1987 Metro-Dade Police Department study revealed that forty-five percent of pursuits conducted in the county resulted in property damage, thirty-four percent in an accident, and twenty-three percent in personal injury); Derek W. Meinecke, Assessment of Police Conduct During High-Speed Chases in State Tort Liability Cases: The Effects of Fiser v. City of Ann Arbor and Rogers v. City of Detroit, 46 WAYNE L. REV 325, 328 (2000) (" $[\mathrm{H}]$ igh-speed police chases carry a significant likelihood of property damage and serious personal injury."); Erik Savas, Hot Pursuit: When Police Pursuits Run over Constitutional Lines, 1988 DetroIt Coll. L. MiCH. ST. U. L. REV. 857, 858 \& n.1 ("In the United States today, police officers are increasingly involved in high-speed police chases where the ultimate result is an assortment of consequences ranging from minor property damage to loss of human life.").

${ }^{183}$ Davis \& Breslau, supra note 153, at 291 ("Certain characteristics of rape, such as ... use of physical force, display of weapons, and victim injury, were observed to be associated with a greater likelihood of PTSD and an excess of PTSD symptoms." (citations omitted)).

${ }_{184}^{185}$ Id.

186 The perspective that police bear a measure of responsibility even for criminal behavior is prevalent. It has been observed:

[Y] ear after year, from the halls of academia, police desks and judges' chambers, we are presented with tired causal explanations of the factors which allegedly underlie criminal behavior-poverty, under-employment, broken homes, drugs, poor education, rising expectations, the age of anxiety, anomie, malaise, personality, ethnicity, community instability, brain biochemistry and so on. But these explanations never satisfy.... The case may be that these explanations, while not completely irrelevant and untrue, while providing some enlightenment and footing for the practical amelioration of crime and criminality in the African American community, may be but manifestations of a deeper, more profound set of variables.

Amos N. WiLSON, BLACK-ON-BLACK VIOLENCE: THE PSYCHODYNAMICS OF BI.ACK SELFANNIHILATION IN SERVICE OF WHITE DOMINATION 16 (1990). The author suggests that police misconduct is a more appropriate causal factor and laments the fact that "[c]ausal explanations which include the character, perspectives, and behavior of the ruling group as a part of the problem, are designated 'radical' by establishment aca- 
is also evidence indicating that police are situated to prevent, arrest, or remedy the antisocial behavior. ${ }^{187}$ Thus, it is possible to consider police at least indirectly responsible for the persistence of such behavior. ${ }^{188}$

Ignoring the role of the police may have adverse consequences for the plaintiff's health. In the context of spousal abuse, psychiatrists are adamant about the obligation of the legal system to help the victim, arguing that "[e]mphasis initially on the use of legal systems to stop the abuse must almost be mandatory, because numerous studies show that treatment is most successful when abusers are forced to admit to themselves and others that they have, in fact, committed crimes." Similarly, a legal unwillingness to hold officers engaging in misconduct accountable could negatively affect a victim's recovery. More broadly, individual psychoses may be undiagnosed, masked by racial stereotypes.

The dismissal of the stress-induced reactions of people of color also has adverse legal consequences in police misconduct litigation. Traumatic experiences suffered by whites as well as people of color present the sufferer with the possibility of a diagnosis of PTSD and the concomitant protection of the ADA. Many traumatic experiences suffered primarily or exclusively by people of color, however, do not lead to a diagnosis of PTSD. ${ }^{190}$ Divorced from any identification with clinical disorders, courts dismiss the stress-induced reactions of people of color as simply "odd," while the stress-induced reactions of whites

demicians and thereby rendered null and void." Id. at 15.

${ }^{187}$ See Leah J. Dickstein, Spouse Abuse and Other Domestic Violence, 11 PsychIATRIC CLINICS N. AM. 611, 618 (1988) (providing a parallel in spousal abuse cases, where it has been noted that "law enforcement can stop abuse more readily and more permanently then [sic] can conciliation, which includes mediation and therapy outside the legal system" (citation omitted)). The notion that police are situated to prevent and arrest antisocial behavior is reinforced by the fact that police officers are often the first caregivers in lower socioeconomic groups. See John A. Talbott \& Susan W. Talbott, Training Police in Community Relations and Urban Problems, 127 AM. J. Psychiatry 894, 894 (1971) (discussing the importance of training the police on mental health issues because "policemen are frequently the first care givers involved with lower socioeconomic groups").

${ }^{188}$ See Illinois v. Wardlow, 528 U.S. 119, 133 (2000) (noting that "these concerns and fears [regarding the belief among many people of color that it is prudent to avoid police] are known to the police officers themselves, and are validated by law enforcement investigations into their own practices" (footnotes omitted)).

${ }^{189}$ Dickstein, supra note 187 , at 626.

190 See supra notes 155-75 and accompanying text (discussing stressors to which people of color are exposed, such as hate crime violence).

See infra notes 240-46 and accompanying text (discussing a Second Circuit opin- 
may be legitimized and justified with a diagnosis of PTSD. The ADA is therefore interpreted so as not to afford many people of color adequate protection. Meanwhile, victims of color retain the stigma of abnormality that is often associated with disabilities.

\section{Two RaCE-Conscious Proposal.s For FACILITATING SuCCESSFUl POLICE MisCONDUCT CLAIMS BY PLAINTIFFS OF COLOR}

\section{A. Distinguishing the Effects of Racism on the Individual Psyche from the Societal Effects of Racism: Two Proposals}

People of color thus appear to be in a double bind when faced with the prospect of bringing a cause of action against police officers. Section 1983 is intended to benefit people of color, but is technically impotent, and the ADA, while technically viable beyond $\S 1983$, simply is not tailored to serve adequately people of color. Racism plays a role in this disparity.

To approach this problem, one must bear in mind the distinction between conceiving of racism as an atomistic phenomenon, and racism as a pervasive, societal phenomenon. ${ }^{192}$ The prevailing colorblind approach to law maintains that racism in this country is of an atomistic nature, and that instances of racism are deviations from the norm. ${ }^{193}$ Critical Race Theory, by contrast, recognizes that racism is pervasive, and exists as more than the sum of isolated racist occurrences. ${ }^{194}$ It contends that racism can inhere in a society's organizational fiber even when no individual racist aggressor is identified as

ion indicating that an officer's claim that a person's behavior was "odd" satisfies the requirement of reasonable suspicion, even if the officer's precinct is publicly regarded as being infamous for its corrupt police).

192 See, e.g., Girardeau A. Spann, Affirmative Action and Discrimination, 39 How. L.J. 1, 2-3 (1995) (identifying this distinction in discussing the Supreme Court's treatment of racial inequality in Adarand Constructors, Inc. v. Pena, 515 U.S. 200 (1995)).

${ }^{193}$ See id. ("[T]he Court ... treat[ed] racial inequality ... as a problem that has become atomistic rather than pervasive in nature."); supra notes 5-7 and accompanying text (discussing the unjust consequences of the colorblind approach); supra note 9 (discussing white Americans' reticence to acknowledge pervasive racism and the Supreme Court's decision to adhere to that view with respect to police misconduct). In the context of police misconduct "[1]iberals tend to argue for more rights-protective rules, while conservatives tend to advocate rules that give law enforcement more leeway. But both sides agree, at least in principle, that the line should be drawn in the same place for everyone." COLE, supra note 6, at 7; see also id. at 5 (contending that "our criminal justice system affirmatively depends on inequality").

${ }^{194}$ For example, Cole notes that " $[\mathrm{t}]$ he disproportionate numbers of young black men in prison and jail . . cannot be explained by discriminatory policing or prosecuting alone." COLE, supra note 6 , at 22. 
actively engaging in discrimination or inciting hate. In the context of police misconduct, when racially discriminatory police practices are, or would be, permitted by judicial interpretation of a society's laws, Critical Race Theory suggests that pervasive racism exists even if such practices are not applied, or no person of color is directly victimized by such practices. ${ }^{195}$ The passive toleration of such a legal structure itself belies a racist society. If police officers do not accommodate the reactions they elicit in some people of color when those reactions are astutely learned survival mechanisms in response to societal racism, the officers are dismissing the very real experience of racism. By ignoring the effects of pervasive racism, colorblind statutory interpretations endanger suspects of color.

Just as manifestations of racism can be characterized in atomistic or pervasive terms, so can responses to racism. ${ }^{196}$ Consequently, since the colorblind approach to the law only acknowledges atomistic manifestations of racism, it will only consider responses to isolated instances of racism to be legitimate. For instance, if a plaintiff develops a stress disorder as a result of a racial assault, that will be considered of legitimate concern. (Even then, the plaintiff's claim will only be considered legitimate because assaults are recognized as stressful, not because racism is regarded as stressful. ${ }^{197}$ The element of racism is still overlooked.) If, however, an individual develops a stress disorder in response to daily pervasive manifestations of racism (such as not usually being able to catch a cab to get to work on time on account of being black), the law will not act to make the complainant whole again because the law does not recognize the complained-of pervasive racism.

As such, the problem of police misconduct as it applies to people of color is largely handled by looking the other way. ${ }^{198}$ Thus, even ac-

${ }^{195}$ The Supreme Court has ruled, for instance, that when an unconstitutional police policy exists, there is no municipal liability if the policy was not the "moving force" behind, and was not "affirmative[ly] link[ed] to," the violation of the plaintiff's rights. Supra note 109 and accompanying text. So even when the plaintiff is victimized directly, the municipality's unconstitutional practices are not checked.

${ }^{196}$ Some have phrased this distinction in terms of the racist's psyche, rather than the target of racism's psyche: "We must distinguish between individual psychological reasons for the development of anti-black feelings and a pervasive climate of prejudice which stimulates and evokes the potential of race prejudice in everyone." GRIER \& COBBS, supra note 21, at 184.

${ }^{197}$ See supra notes 171-74 and accompanying text (noting that violent assault is recognized as a PTSD-inducing stressor by the DSM-IV, while racially motivated attacks are not).

${ }^{198}$ See supra notes 7,9 (discussing a tendency on the part of some whites to ignore 
knowledging that the problem exists is a giant step forward. As legal and scientific disciplines become more familiar with each other, however, it is difficult to know where to look to identify the ambiguities that perpetuate inequity. An analysis of the ADA offers unique insight into the logic behind the courts' treatment of claims of misconduct and how it affects people of color. ${ }^{199}$

First, it exposes a contradiction in statutory rationale. In its effort to eliminate one form of discrimination (based on disability) by adhering to clinical definitions of PTSD, it tolerates another form of discrimination (based on race). Second, it illustrates how Congress's stated purpose of eliminating discrimination against people with disabilities and people of color is undermined. Looking at how much help judges have allowed Congress to provide plaintiffs under the ADA demonstrates that courts can facilitate successful suits if they need to do so. It underscores how little help plaintiffs of color have received in comparison to other groups of plaintiffs, even though plaintiffs of color may experience a similar degree of discrimination. Finally, as this portion of the Comment will argue, analyzing the treatment of PTSD in particular under the ADA illustrates how futile and unduly complicated it is to find what amounts to a proxy (such as PTSD) for the stresses of racism to address the impact race has on police interactions.

This comparison of the ADA to $\S 1983$ ultimately provides impetus for proposals to enact race-conscious legislation that obliges judges to explicitly recognize that race directly and fundamentally affects the nature of police interactions. This portion of the Comment will submit and consider two proposals for facilitating remedies for police misconduct victims of color.

the occurrence of racism).

${ }^{199}$ Sociologist Leslie Miller notes that "[p]ower is exercised ... in sites where ... struggles have been silenced." Leslie J. Miller, Claims-Making from the Underside: Marginalization and Social Problems Analysis, in CONSTRUCTIONIST CONTROVERSIES: ISSUES IN Social Problems Theory 153, 167 (Gale Miller \& James A. Holstein eds., 1993). She warns that it is incorrect to assume "that members of subordinate groups will everywhere and always" adopt a certain strategy of voicing themselves. Id. at 173 . In light of such comments, it should, of course, be recognized that many people of color may find it undesirable to compare their reactions to disabilities or PTSD at all, even for the sake of concluding that such reactions are fundamentally distinct from any such disability. There is no reason to assume that some people of color have not already considered addressing the ADA's treatment of police-induced stressors and declined the proposition. Miller's caveat that exclusion from a dominant discourse may represent an act of resistance rather than a reflection of the status quo indeed may apply in the circumstances surrounding PTSD and police misconduct. 
The first proposal is intended to acknowledge the effects of racism on the traumatized individual victim of color's psyche by expanding the ADA's substantive benefits. Specifically, it would revise the clinical definition of PTSD to include a broader range of stressors, such as racist encounters, so that the ADA would include victims of racial discrimination-based trauma within its purview.

The second proposal is designed to acknowledge the effects of racism on people of color at the societal level (whether they display symptoms of stress disorders or not) by exporting the ADA's procedural benefits. In other words, Proposal Two solicits a new statute that shifts the emphasis away from legitimizing the plaintiffs' reactions, and toward admonishing the misconduct of the defendant police, explicitly providing the blanket forms of statutory relief available under the $\mathrm{ADA}^{200}$ to police misconduct victims of color.

The distinctions between atomistic and pervasive conceptions of racism, and between individual and societal responses to racism, are integral to assessing the two proposals submitted above. Proposal One would facilitate plaintiffs' claims, even when those claims must be couched in atomistic terms in keeping with the present statutory regime, by arguing for a clinical acknowledgement of how racism affects the individual psyche. Proposal Two, however, argues that the atomistic understanding of racism should be abandoned in recognition of racism's pervasive nature. Proposal Two, therefore, facilitates plaintiffs' claims by acknowledging how racism affects them societally. The ADA informs both proposals, and reflects the need for race-conscious approaches to police misconduct in both proposals, but in ways that must be recognized as distinct.

\section{B. Proposal One: Substantive Expansion of the ADA to Acknowledge the Impact of Racism on the Individual Psyche}

1. Acknowledging the Impact of Racism as a Psychological Stressor

Embracing an interdependency of law and psychology, courts increasingly have relied upon the professional opinions of psychiatrists to address legal issues involving mental disorders ${ }^{201}$ (often referring to

\footnotetext{
${ }^{200}$ See supra Part II.B (discussing the procedural advantages that make blanket forms of statutory relief available under the ADA).

${ }^{201}$ Addressing the American Psychiatric Association at his Guttmacher award lecture in 1988, law professor Daniel W. Shuman argued that the profession of psychiatry bears an obligation to aid the courts in assessing accurately the various symptoms of PTSD. He emphasized that a failure to make the features of PTSD clear to the courts
} 
the DSM specifically), ${ }^{202}$ and to provide guidance as to what constitutes the forms and symptoms of particular mental illnesses. ${ }^{203}$ However, the reliance that courts place on psychiatric expertise in many instances is unduly exaggerated, if not unfounded, because it is based on an inflated notion of scientific objectivity, which in turn is rooted in a belief that scientists are capable of distilling the relevant complex causal interactions to unassailably objective facts. ${ }^{204}$ As with other sci-

not only may damage the credibility of the field of psychiatry, but also may entail a loss of accuracy in the judicial system. See Ralph Slovenko, Legal Aspects of Post-Traumatic Stress Disorder, 17 PSYCHIATRIC Clinics N. AM. 439, 445 (1994) (paraphrasing Shuman's assertion that if "child sexual abuse syndrome" is not demonstrated to give rise to commonly known or "commonly understood" symptoms, the psychiatric profession must clarify this for the courts (citing David M. Shuman, The Diagnostic and Statistical Manual of Mental Disorders in the Courts, BULL. AM. ACAD. PSYCHIATRY \& L., 1989, at 25)).

${ }^{202}$ See supra note 151 (providing examples of such cases). It has been noted that while a "psychiatric diagnostic category is not essential to a cause of action, . . . the listing of stress reactions in the American Psychiatric Association's DSM has tended to give the claim more legitimacy," so that trauma victims increasingly have used that formulation of PTSD in lawsuits. Slovenko, supra note 201, at 441. These remarks underscore courts' unwillingness to assess independently any PTSD-related clinical data that is not processed through the filter of psychiatric opinion.

${ }^{203}$ See I.C.H. Clare \& G.H. Gudjonsson, Interrogative Suggestibility, Confabulation, and Acquiescence in People with Mild Learning Disabilities (Mental Handicap): Implications for Reliability During Police Interrogations, 32 BRIT. J. CLINICAL PSYCHOL. 295, 295 (1993) (noting that "[i]n the last decade, psychologists have been asked, with increasing frequency, to prepare reports for the court" that are of a clinical nature).

${ }^{204}$ Challenges to the concept of objective fact achieved through analyses of how knowledge is constructed have deep philosophical roots. Several Continental European schools of thought, ranging from Heidegger and the hermeneuticists to the French postmodernists (e.g., Baudrillard, Deleuze, and Guattari), to the Frankfurt School (e.g., Habermas, Horkheimer, and Adorno) are often accredited with influencing these challenges. American scholars such as Dewey and Kuhn also offered similar analyses. The Frankfurt School in particular has set the stage for the work of many of the scholars mentioned above. See, e.g., Jürgen Habermas, Theory and Practice 5 (John Viertel trans., 1973) (examining the consequences of "the circumstance that science increasingly plays the role of a primary force of production"); MAX HORKHEIMER \& THEODOR W. ADORNO, DIALECTIC OF ENLIGHTENMENT, at xi (John Cummin trans., 1972) (arguing that "[i]f the assiduous maintenance and verification of the scientific heritage are an essential part of knowledge ... not only the pursuit but the meaning of science has become problematical"). While the above philosophers are commonly recognized as influencing studies of scientific thought, the conclusions many of them reach have been addressed by, and derive significant if unheralded influence from, nonwhite and non-Western scholarship and philosophies. See generally, e.g., THE "RACial" ECONOMY OF SCIENCE: TOWARD A DEMOCRATIC FUTURE (Sandra Harding ed., 1993) (discussing sciences of China, Africa, and South America, and reevaluating the assumptions of Western science); SCIENCE, HEGEMONY AND VIOLENCE: A REQUIEM FOR MODERNITY (Ashis Nandy ed., 1996) (criticizing the notion that a scientific approach is always superior to other forms of inquiry and assessing the impact of that approach). 
entific disciplines, ${ }^{205}$ the clinical conclusions of psychiatry are as much the product of value-laden cultural and social factors as they are of objective observation. ${ }^{206}$ Far from being an impartial provider of objective clinical data (as evidenced by the discussion in Part III), the psychiatric profession is also prone to include potentially legally relevant assumptions and value judgments in its very definition of PTSD. ${ }^{207}$ This may result in clinicians depriving people of color (irrespective of whether it is done intentionally or not) of the benefits of legal remedy by constructing what still may be an underinclusive definition of PTSD.

When assessing a cause of action, courts are empowered to identify such subjective value judgments in the facts presented to them. But often the courts are equally, if not more, willing to engage in similar value judgments. The same type of criticisms that expose scien-

${ }^{205}$ Even clinical or laboratory results obtained in the "hard" sciences like biology long have been recognized to be subject to the idiosyncrasies of the individuals conducting the research. In their landmark study of a bioassay laboratory, for instance sociologists Bruno Latour and Steve Woolgar examine how facts are constructed, noting that "the epistemological qualities of validity or wrongness cannot be separated from sociological notions of decisionmaking." BRUNO LATOUR \& STEVE WOOLGAR, LABORATORY Life: The Construction of Scientific Facts 121 (Princeton Univ. Press 1986) (1979). In short, statements understood as scientific "facts," like the diagnoses of PTSD, are malleable and context sensitive. Deciding whether to label reactions to police as being evidence of PTSD requires an analysis of the cultural processes at work in defining PTSD in the first place.

${ }^{206}$ The speciousness of the conception of psychiatry as being a science capable of isolating objective scientific truths is highlighted by the fact that clinicians themselves disagree about how to define psychiatric phenomena. See supra notes 152-54 and accompanying text (describing progressive clinicians' criticisms of the current definition of PTSD as being too narrow). Even a cursory look at the definitions of PTSD offered by clinicians testifies to the potential for infusing value judgments in psychiatric diagnoses and the definitions' relatively ambiguous nature. The definition of PTSD evolves with a rather rapid rate of transformation, lending credence to the notion that there is no one correct and indisputable definition of PTSD. See infra note 214 (describing the discrepancies between the definitions of PTSD given in the DSM-III and DSM-IV). Any given scientific "fact"-including any definition of a stress disorder-therefore must be considered in light of the social environment in which it was created. Sociologists note that "[e]ven a well-established fact loses its meaning when divorced from its context," and "can take on a different meaning and significance depending on the particular network of individuals for which it has relevance," varying according to its usage. LATOUR \& WOOLGAR, supra note 205, at 110 . When the social environment tolerates discriminatory police misconduct, even the rigor of the relevant science must be examined for taint.

${ }^{207}$ Latour and Woolgar suggest that attempts at persuasion affect how scientific facts are constructed. LATOUR \& WOOLGAR, supra note 205, at 81. Scientists, like judges, are aware of this critique, and they take pains to erase any indication of subjectivity or persuasiveness that could tarnish any claims to impartial, objective fact production. Id. at 76. 
tists' utter lack of objectivity, despite claims to the contrary, are levied convincingly against judges as well. ${ }^{208}$ Professor Paul Butler, for instance, reports that " $[\mathrm{w}]$ hen judges 'decide' cases, they 'choose' legal principles to determine particular outcomes." ${ }^{209}$ Similarly, judges "choose" when to apply clinical definitions.

Jody D. Armour's discussion of the Florida case of Jandrucko $v$. Colorcraft/Fuqua Corp., ${ }^{210}$ illustrates this point. In Jandrucko, a fifty-nineyear-old white woman successfully filed a workers' compensation claim indicating that she had developed a form of PTSD that caused physical and psychological reactions to blacks-particularly "big, black males"- after being mugged by a black male while on the job as a customer service employee. The court accepted that her fear of "big, black males" rendered her incapable of finding gainful employment and awarded the plaintiff total disability benefits for her phobia. ${ }^{211}$ The presiding judge commented that the plaintiff's pathological fear of blacks was not an exercise of "'private racial prejudice," but rather was a "work-related phobia." "12

Thus, by the time the effect of race and racism on a plaintiff's personal psychology is ruled on, it has been filtered through two potentially biased screens-that of clinicians, and that of the judge. This has direct consequences for the efficacy of ADA claims that rely on purportedly objective definitions of stress disorders. Basing the viability of a claim on the definition of the plaintiff as a prototypical victim

${ }^{208}$ Critical Legal Studies theorists, and later Critical Race theorists, have long argued that judicial decisions, despite their claim to objectivity, are value laden. See generally The Politics of LAW: A Progressive CRITIQUe 641-717 (David Kairys ed., 3d ed. 1998) (providing discussions on this theme).

${ }^{209}$ Paul Butler, Racially Based Jury Nullification: Black Power in the Criminal Justice System, 105 YALE L.J. 677, 707 (1995). Butler adds, "even if neutrality were possible, it would not be desirable, because no general principle of law can lead to justice in every case." $I d$. It is similarly unlikely that a general definition of what constitutes erratic social or psychological behavior will always ensure that the definition will be applied in a just manner. If people of color who are in fact suffering from a stress disorder cannot count on receiving a proper diagnosis, or if their particular circumstances are not addressed, they may be hampered in their efforts to determine which would be the most appropriate medical or social support systems to approach in order to expedite their recovery. The legal system itself should be one such social support system at the service of people of color faced with questionable diagnoses. The lack of such support may directly impede recovery.

${ }^{210}$ No. 163-20-6245 (Fla. Dep't of Labor \& Employment Sec., Apr. 26, 1990).

211 Jody D. Armour, Race Ipsa Loquitur: Of Reasonable Racists, Intelligent Bayesians, and Involuntary Negrophobes, 46 STAN. L. REV. 781, 800 (1994).

${ }^{212}$ William Booth, Phobia About Blacks Brings Workers' Compensation Award, WASH. POST, Aug. 13, 1992, at A3 (quoting the workers' compensation judge, John G. Tomlison, Jr. who awarded the plaintiff disability). 
gives those who define the prototype, whether psychiatrist or judge, a gatekeeping power to prevent certain groups of people from having remedies available to them.

This is especially problematic when mental disabilities are at issue in the context of police misconduct because there is evidence that clinical dispositions toward those disabilities are influenced directly by the police. ${ }^{213}$ If the police engage in discriminatory misconduct, their influence on clinical assessments of patients of color will be similarly biased.

One strategy for establishing a more equitable distribution of justice, therefore, would be to argue for a race-conscious revision of the interpretation of stress disorders like PTSD under the ADA -one that would acknowledge the seriousness of racist stressors. Indeed, the definition of PTSD used by the courts is not the only definition available, nor is it necessarily the best or most accurate definition ${ }^{214}$-particularly in light of evidence that people of color are underdiagnosed with PTSD. ${ }^{215}$ Some clinicians have, in fact, already hinted that it would be desirable to expand the definition of PTSD. ${ }^{216}$ Explicitly acknowledging the effects racism may have on an individual's psy-

${ }^{213}$ See Mary L. Durham et al., Police Involvement and Influence in Involuntary Civil Commitment, 35 HOSP. \& CMTY. PSYCHIATRY 580, 580 (1984) (concluding from empirical study that police exercise undue influence over clinical decisions to admit patients to psychiatric institutions). But see Margaret A. Watson et al., Police Referral to Psychiatric Emergency Services and Its Effect on Disposition Decisions, 44 HosP. \& CMTY. PSYCHIATRY 1085,1085 (1993) (arguing that police in their study did not exercise undue influence on clinical admission decisions).

${ }^{214}$ According to the DSM-IIIR, published in 1987, "The essential feature of this disorder is the development of characteristic symptoms following a psychologically distressing event that is outside the range of usual human experience (i.e., outside the range of such common experiences as simple bereavement, chronic illness, business losses, and marital conflict)." AM. PSYChIATRIC Ass'N, Diagnostic and STATISTICAL MANUAL OF MENTAL DISORDERS 247 (3d. rev. 1987) [hereinafter DSM-IIIR]. Seven years later, the DSM-IV altered the definition of PTSD. See supra note 150 (quoting the DSM-IV definition of PTSD). Both definitions grant ample leeway for value-laden interpretations. What "is outside the range of usual human experience" depends on which humans and which experiences are being considered. The later definition provided in the DSM-IV, although more elaborate, is equally subjective, referring to "characteristic symptoms following exposure to an extreme traumatic stressor." Both definitions are struggling to put forth criteria whereby what is "normal" can be diagnostically distinguished from what is "abnormal" or anomalous. What makes these distinctions problematic is not their very existence: Rather, it is the notion that such distinctions are impartial, objective, and factually unassailable, and therefore "correct," that is misleading.

${ }^{215}$ See supra notes 155-75 and accompanying text (discussing evidence that people of color are underdiagnosed with PTSD).

${ }^{216}$ See supra notes 153-54 (examining various criticisms of the definition of PTSD). 
che-for example, by adjusting the definition of PTSD-would expand the domain of viable causes of action in police misconduct litigation under the ADA for some people of color. ${ }^{217}$

Proposal One would facilitate claims for people of color under the ADA in a manifestly race-conscious manner by acknowledging that not only is police misconduct a stressor, but so is the racial discrimination that often accompanies it. In that respect, an expansion and direct application of the ADA is appropriate. The rationale underlying the ADA is that it protects and legitimizes anomalous behavior. As discussed in Part III, disabilities generally are viewed as atypical characteristics shared only by "a discrete and insular minority."18 Judges may legitimize atypical plaintiff conduct under the ADA by attributing it to that individual's disability. ${ }^{219}$ This is an appropriate rationale for helping persons with stress disorders who happen to be people of color. It may even be appropriate for helping people of color who develop disorders in response to racist stressors that are anomalous even among people of color. ${ }^{220}$

\section{Why a Substantive Expansion of the ADA Is Not Enough}

While direct substantive application of the ADA may be appropriate for addressing how racism may traumatize a given individual psyche, however, the rationale of the ADA is not appropriate for addressing societal racism. Even if the ADA is expanded substantively such that racist stressors are acknowledged as being precipitating causes of diagnosable stress disorders, such a proposal still does nothing to help people of color who are subject to the same racist stressors even though they have not developed stress disorders in response.

As discussed above, there is evidence that racist externalities can develop or intensify mental illnesses in a given individual's psyche. ${ }^{2.1}$

${ }^{217}$ One serious caveat of such a proposal is that it may result in patients being diagnosed against their will, which can subject unwilling patients to medication and confinement. See, e.g., MichaEl Shapiro \& Roy G. SPECE, JR., Bioethics AND LAW: CaSES, MATERIALS, AND PROBLEMS 168-73 (1981) (noting that when patients are deemed "ill," they may receive nonconsensual treatment when such treatment would not be otherwise permitted).

28 Supra text accompanying note 128. ample).

219 See supra notes 15, 126, 136, and accompanying text (discussing one such ex-

${ }^{220}$ See infra note 237 (suggesting that relativizing a person's psychology by comparing it to the norm within that person's race may be an appropriate means of identifying who is a proper subject for therapy).

${ }^{221}$ See supra notes $155-75$ and accompanying text (indicating that stressors to 
Distinct from the effect of racism on the individual psyche is the existence of stressors associated with racism that permeate society as a whole, and which affect all people of color-not just those persons who develop mental illnesses as a response. The potential effects of racism on the individual and the effects of racism on society at large must not be conflated. It is a logical fallacy to conclude that since persons who develop mental illnesses in response to racism are people of color, only people of color who suffer from mental illnesses (or otherwise act abnormally) experience racism-and that everyone else is just overly sensitive. ${ }^{222}$

Current statutory interpretations, however, encourage precisely this error of conflating individual with societal responses to racist police misconduct. The courts' acknowledgement of the ADA as a legitimate tool for police misconduct plaintiffs, while rendering most $\S 1983$ claims ineffectual, ${ }^{223}$ suggests that certain prototypes exist that are more likely to be regarded as representative of legitimate police misconduct victims than others. Persons with physical or mental disabilities are models of the "type" of person who may legitimately claim victimhood in the face of the police. People of color, however, are less likely to be viewed as legitimate claimants of police misconduct. As a result, an implicit motivation exists for plaintiffs' attorneys to pigeonhole clients who wish to sue police as being disabled, with little or no emphasis placed on any pertinent stressors associated with racial discrimination. Facilitating effective claims against racist police by people of color only when the plaintiff displays a mental illness-even if the definition of mental illness is expanded to acknowledge racial stressors, as per Proposal One-implicitly leads to the bizarrely inappropriate conclusion that unless a person of color is mentally ill, she has not experienced actionable misconduct.

By presenting the plaintiff with the option of either portraying

which people of color are disproportionately exposed and explicitly racist stressors such as racially motivated personal attacks may exacerbate PTSD).

${ }^{222}$ Nonetheless, such interpretations are prevalent. Even psychologists note that "[w] hite Americans have developed a high skill in the art of misunderstanding black people." Grier \& COBBS, supra note 21, at 210. "Whites often argue that Blacks are simply too sensitive or that the argued instance of discrimination is "all in their head." Broman et al., supra note 8 , at 178 . Similarities in patterns of response to inquiries about whether people of color felt racism in a given year indicated that it is extremely unlikely that fabricated, exaggerated, or random reports of racism from two different samples would yield such similar results in the reported frequencies of the specific racist acts." Klonoff \& Landrine, supra note 8, at 242.

${ }^{223}$ See supra notes 58-77 and accompanying text (dismissing judicial treatment of $\S 1983)$. 
herself as mentally ill, or pursuing a $\S 1983$ claim that is unlikely to succeed, the present statutory regime in effect pressures the plaintiff to apply the rationale of the ADA to claims for which it is not appropriate. It is not appropriate because the ADA, in effect, may legitimize atypical plaintiff conduct by attributing it to that individual's disability. ${ }^{224}$ The ADA thus obliges the judge to ask whether an officer should have known that someone with a disability similar to the plaintiff's would react as the plaintiff did, and to legitimize formally the plaintiff's reaction to the police in some cases. The implied rationale behind the ADA is thus to protect the atypical reactions of those whom Congress has determined "as a group, occupy an inferior status in our society." 225 But, as discussed in Part III, the plaintiff's reaction itself-though legitimized-is still considered anomalous, or abnormal.

The crucial point is that the adverse reactions of many people of color should not even reach the stage of being legitimized (as the reactions of those considered to be persons with disabilities under the $\mathrm{ADA}$ are), because their reactions are not abnormal in the first place. At present, in the context of police misconduct, reasonable reactions to the police are equated with typical reactions, and "blame is reserved for the (statistically) deviant.",226 Problems arise when typical behavior is conceived of as being synonymous with reasonable behavior. ${ }^{227}$ The

${ }^{224}$ See supra notes 15,126 and accompanying text (describing how courts legitimize conduct under the ADA).

${ }^{225} 42$ U.S.C. $\$ 12101$ (a)(6) (1994); see also supra text accompanying notes 128-31 (discussing Congress's reasons for creating the ADA).

${ }^{226}$ I borrow this phrase from Armour, supra note 211, at 787 (quoting Mark Kelman, Reasonable Evidence of Reasonableness, 17 CRITICAL INQUIRY 798, 801 (1991)).

${ }_{227}$ Jody D. Armour makes this point in her discussion of the "Reasonable Racist," who believes that he should be excused for considering a victim's race before using force on the victim because the majority of similarly situated people also would have done so. "For even if the 'typical' American believes that blacks' 'propensity' toward violence justifies a quicker and more forceful response when a suspected assailant is black," writes Armour, "this fact is legally significant only if the law defines reasonable beliefs as typical beliefs. The reasonableness inquiry, however, extends beyond typicality to consider the social interests implicated in a given situation. Hence not all "typical' beliefs are per se reasonable." Armour, supra note 211, at 788 (emphasis added). She further explains her distinction:

Typical beliefs may be considered reasonable for two very different reasons. First, they are presumed to be accurate. .. . Accordingly, typical beliefs about the propensity of blacks towards violence are reasonable insofar as we have no reason to doubt them. . . .

Second, typical beliefs may be considered reasonable on the supposition that they are not blameworthy, however inaccurate or even irrational they may be. This is the claim of reasonableness invoked by ... the Reasonable Rac- 
reactions of people of color to traumatic stressors such as police misconduct may be atypical only from the perspective of the white majority. ${ }^{228}$ Those reactions, however, are not unreasonable by virtue of their atypicality as judged by their deviation from a white norm. Indeed, from the perspective of many other people of color (and perhaps some whites), adverse reactions to the police are not even properly characterizable as atypical, but rather are rational responses to stressful situations.

Many in the legal community acknowledge the effects of societal racism. Law professor Paul Butler has noted that he "sympathize[s] with people who react 'negatively' to the countless manifestations of white supremacy that black people experience daily. ... The antisocial conduct is no more evil than the conditions that cause it . . ."229 Speaking in terms of criminal conduct in particular, he argues that such conduct "among African-Americans is often a predictable reaction to oppression. Sometimes black crime is a symptom of internalized white supremacy; other times it is a reasonable response to the racial and economic subordination every African-American faces every day. ${ }^{230} \mathrm{He}$ adds that "[p] unishing black people for the fruits of racism is wrong if that punishment is premised on the idea that it is the black criminal's 'just desserts. ${ }^{\text {'231 }}$

There is a large body of psychological and psychiatric literature supporting this viewpoint, documenting the existence of societal racism and its psychological effects on people of color. ${ }^{232}$ One commen-

ist .... According to this claim, even admittedly wrong judgments about a fact or situation should be excused so long as most people would have reached the same wrong conclusions under similar circumstances. This argument rests on the premise that "we are blamed only for those actions and errors in judgment that others would have avoided."

Id. (citation omitted).

${ }^{228}$ See supra note 9 (citing one authority characterizing the Supreme Court majority's opinion to be that "we all have the same set of experiences vis-à-vis the police"); infra note 277 . (citing one authority arguing that the Supreme Court's involvement in allocating resources boosts the interests of the white majority); see also, e.g., Jean Johnson, Americans' Views on Crime and Law Enforcement: Survey Findings, NAT'L INST. JUST. J., Sept. 1997, at 9, 13 (reporting a study by the Joint Center for Political and Economic Studies which found that forty-three percent of African Americans consider police misconduct toward African Americans to be a serious problem in their own communities).

229 Butler, supra note 209, at 716 .

${ }^{230} I d$. at 680 .

${ }^{231} I d$.

${ }^{232}$ See, e.g., Klonoff \& Landrine, supra note 8, at 234 (finding that ninety-six percent of blacks experienced racism within one year's time, and that experiencing racism 
tator approaching the dilemma from a psychoanalytical perspective poses the question: "What better way to 'provoke deadly but necessary' violence against the African American community than first to criminalize that community and then execute it for its alleged criminality?" Ans Another legal commentator echoed this concern, noting further:

Those who live in high crime areas will likely be poor and members of minority groups, and these very same people may also have strong reasons to avoid the police, given their past experiences. Thus, if the law allows stops based on membership in just these two categories, it effectively allows police nearly complete discretion to stop African Americans who live in crime-prone urban neighborhoods. ${ }^{234}$

Not only are many responses to racism characterized by employing the double negative "not unreasonable"-they are often patently, affirmatively rational. Among the more famous psychoanalyses of societal racism is the work of William H. Grier and Price M. Cobbs, who note that "[f]or a black man survival in America depends in large measure on the development of a 'healthy' cultural paranoia." ${ }^{295}$ They suggest that even if people of color actually violate the law (instead of simply being innocent targets of racial profiling by police), their behavior is still reasonable:

[The black man in America] can never quite respect laws which have no respect for him, and laws designed to protect white men are viewed as white men's laws. To break another man's law may be inconvenient if one is caught and punished, but it can never have the moral consequences involved in breaking one's own law. The result may be described as a cultural antisocialism, but it is simply an accurate reading of

was strongly related to total psychiatric symptoms); Hope Landrine \& Elizabeth A. Klonoff, The Schedule of Racist Events: A Measure of Racial Discrimination and a Siudy of Its Negative Physical and Mental Health Consequences, 22 J. BLACK PSYCHOL. 144 (1996) (exploring evidence in support of the notion that racial discrimination is relatively common and serves as a culturally specific stressor for blacks in America); Vonnie C. McLoyd, Conceptual and Methodological Issues in the Study of Ethnic Minority Children and Adolescents, in CHILdREN of COLOR: RESEARCH, HEALTH, AND POLICY ISSUES 3 (Fitzgerald et al. eds., 1999) (finding that children of color may have more behavior and emotional problems than their majority counterparts); see also supra note 8 (discussing societal racism as manifest by police misconduct).

${ }^{293}$ WILSON, supra note 186, at 52.

${ }^{234}$ David A. Harris, Particularized Suspicion, Categorical Judgments: Supreme Court Rhetoric Versus Lower Court Reality Under Terry v. Ohio, 72 ST. JOHN's L. REV. 975, 1000 (1998).

${ }^{295}$ GRIER \& COBBS, supra note 21, at 161 . 
one's environment-a gift black people have developed to a high degree, to keep alive. ${ }^{236}$

They emphasize that antisocial responses to a racist environment must not be understood as evidence of psychoses, but as reasonable reactions. "These and related traits are simply adaptive devices developed in response to a peculiar environment. They are no more pathological than the compulsive manner in which a diver checks his equipment before a dive or a pilot his parachute."237

Federal court opinions (and dissenting opinions of the Supreme Court) recognize that it is not unreasonable for people of color to be suspicious of, and to react defensively to, the police. Justice Stevens, writing for the dissent in Illinois $v$. Wardlow, noted that for minority citizens living in high crime areas in particular, aversion to, or even outright flight from, police officers "is neither 'aberrant' nor 'abnormal'.... Accordingly, the evidence supporting the reasonableness of these beliefs is too pervasive to be dismissed as random or rare, and too persuasive to be disparaged as inconclusive or insufficient." ${ }^{238}$

The Wardlow dissent, addressing the defendant's flight at the sight of police officers, recognized that

[a]mong some citizens, particularly minorities and those residing in high crime areas, there is also the possibility that the fleeing person is entirely innocent, but, with or without justification, believes that contact with the police can itself be dangerous, apart from any criminal activity associated with the officer's sudden presence. ${ }^{239}$

District courts also have questioned the abnormality of adverse reactions to police based on race. In 1996, Judge Harold Baer, presiding in the Southern District of New York, issued a ruling in which he suppressed the admission of evidence under the "fruit of the poisonous tree" doctrine, which requires a judge to suppress any evidence seized by virtue of a stop that violates a defendant's constitutional

296 Id. at 178 .

${ }^{237} I d$. "It is a normal complement of psychological devices," they add, "and to find the amount of sickness a black man has, one must first total all that appears to represent illness and then subtract the Black Norm. What remains is illness and a proper subject for therapeutic endeavor." Id. at 179.

${ }^{238} 528$ U.S. 119, 133-34 (2000) (Stevens, J., concurring in part and dissenting in part). The fact that this opinion was voiced in dissent does not detract from its validity, but rather illustrates the need for a statutory means of imbuing this acknowledgment with legal bite.

${ }^{239}$ Id . at 132. 
rights. ${ }^{240}$ The defendant, a middle-aged black woman, was arrested at 5:00 a.m. after she pulled away from four males who had placed duffel bags in the trunk of the car she was driving. The issue was whether the defendant's Fourth Amendment rights were violated-whether she was arrested without reasonable suspicion. ${ }^{241}$ The judge stated,

240 See United States v. Bayless, 913 F. Supp. 232, 238 (S.D.N.Y. 1996) ("If the initial stop of defendant's vehicle violated defendant's Constitutional rights, any subsequent search or evidence seized by virtue of the violative stop will be suppressed under the 'fruit of the poisonous tree' doctrine." (citing Wong Sun v. United States, 371 U.S. 471, 484-85 (1963))).

${ }^{241}$ See Bayless, 913 F. Supp. at 237 ("The inquiry here is whether the evidence seized and the statements given were the fruits of a search and seizure made in violation of the defendant's Fourth Amendment rights."). Judge Baer noted at the outset: "I find [defendant's] statement to be credible and reject the testimony proffered by [the arresting] Officer Carroll," $i d$. at 234, thus discrediting the officer's claim that at least one of the males ran from the scene upon becoming aware of the police officers' presence, $i d$. at 241 . The judge added that the defendant's "candor and the breadth and nature of her statements give her statement great credibility." Id. at 236. "The testimony offered by Officer Carroll about how the events ... unfolded when juxtaposed with the defendant's full fledged videotaped confession suggest that Officer Carroll's testimony is at best suspect." Id. at 239.

Judge Baer continued:

Moreover, even assuming that one or more of the males ran from the corner once they were aware of the officers' presence, it is hard to characterize this as evasive conduct. Police officers, even those travelling in unmarked cars, are easily recognized, particularly, in this area of Manhattan. In fact, the same United States Attorney's Office which brought this prosecution enjoyed more success in their prosecution of a corrupt police officer of an anti-crime unit operating in this very neighborhood. Even before this prosecution and the public hearing ... residents in this neighborhood tended to regard police officers as corrupt, abusive and violent. After the attendant publicity surrounding the ... events, had the men not run when the cops began to stare at them, it would have been unusual.

Id. at 242 (footnotes omitted). In a footnote the court notes:

The United States Attorney for the Southern District of New York spent four years investigating and prosecuting claims that officers assigned to the Washington Heights' anti-crime unit Local Motion for corruption and unjustified arrests. During the investigation Assistant United States Attorneys assigned to the case interviewed numerous individuals who aided in uncovering evidence that members of the anti-crime unit committed perjury or made false statements in connection with various arrests and the prosecution of both federal and state crimes. Meanwhile, the 34th precinct leads the city in corruption complaints filed against its officers.

Id. at $242 \mathrm{n} .18$ (citations omitted).

The judge was critical of not only the officers' claim that being in a high-crime area suggests that one is engaging in illegal activity, but also of the police's characterization of a particular area as being crime-ridden in the first place. "Interestingly," writes Judge Baer, "the Government offered no proof to corroborate their statement that the area surrounding 176 th Street and St. Nicholas Avenue is a known hub for the drug trade." Id. at 240 n.12. 
" $[w]$ hat I find shattering is that in this day and age blacks in black neighborhoods and blacks in white neighborhoods can count on little security for their person." 242

Occurring during an election year, "[t]he decision ... quickly became the focus of a nationwide controversy and a flashpoint for the 1996 presidential campaign, as Democrats and Republicans competed to enhance their reputations as proponents of law and order by denouncing Judge Baer." ${ }^{243}$ Baer ultimately vacated his own prior decision. ${ }^{244}$ The defendant appealed, and the appellate court affirmed the admission of evidence, noting that:

[t] he strange behavior of the men who loaded the duffel bags into the trunk of her car ... is itself an appropriate and weighty factor.... This weighty factor makes the case before us easy... . [T] he men's odd behavior while loading the car makes factors such as the high-crime neighborhood and flight more significant. ${ }^{245}$

The appellate court missed the point. It is not the significance of the "strange" and "odd" behavior itself that is problematic. It is the rationale underlying the characterization of the behavior as "odd" in the first place that ignores the specifically racial context of the situation. When people of color act "oddly" around police officers in highcrime areas, according to the appellate court, that makes a decision such as this "easy," and suffices as a "weighty factor" that converts all previously dubitable factors into "facts and circumstances... suffi-

${ }^{242}$ Id. at 240 . The area in question, Washington Heights, is largely populated by Latino and Black residents.

${ }^{243}$ United States v. Bayless, 201 F.3d 116, 123 (2d Cir. 2000). Judge Baer himself noted that "while I was surprised at the fire storm that developed . . . to me the fallout constituted little more than political posturing-some of what I saw I cannot say I am proud of-but political posturing in an election year, nevertheless." Id. at 125 (alterations in original) (citing Judge Baer's denial of a motion for recusal from the bench). After the election was over, President Clinton acknowledged that "people of color continue to have less confidence and less trust [in the police], and believe that they are targeted for actions by the police not because of their illegal conduct, but because of the color of their skin." President Clinton, Remarks by the President on Civil Rights Law Enforcement at the Opening of Civil Rights Roundtable at the Marriot Wardman Park Hotel, Wash., D.C. (June 9, 1999), available at LEXIS.

${ }^{244}$ The judge did so after hearing new evidence supplied by a sergeant whose testimony was not included in the initial hearing. United States v. Bayless, 921 F. Supp. 211, 216-17 (S.D.N.Y. 1996).

${ }^{245}$ Bayless, 201 F.3d at 134 (emphasis added). The "strange" behavior referred to was " $[t]$ he speed with which the men loaded the bags into the trunk and dissociated themselves from the car, together with the absence of any communication between the driver and the men." $I d$. 
cient to give rise to reasonable suspicion." ${ }^{246}$ Just as courts ignore race in context when they reduce a complex set of variables to a not impartial definition of PTSD, similarly they ignore the role race may play when they define behavior as "odd." The resulting choices with which victims of color are left are hazardous: showing deference to the police, being nervous around them, and avoiding them will constitute suspicious behavior-but questioning their authority, or even making one's presence known to them, will likely lead to harassment.

Dismissal of pervasive racial stressors may have a more profound effect than simply preventing plaintiffs of color from succeeding in criminal trials or police misconduct cases. It reflects a disregard for the autonomy of individuals of color. ${ }^{247}$ It interferes with the right of people of color to participate in society. ${ }^{248}$ It engenders an understanding that things that disproportionately stress people of colorsuch as police misconduct - are not as important, as legitimate, or as objectively "real" as things that stress whites. It may reinforce stereotypes about antisocial or criminal behavior among people of color. ${ }^{249}$ Dismissing the experiences of a marginalized people of color can even be conceived as a "discursive strategy" that can "depoliticize talk and keep [the problems of people of color] off" ${ }^{250}$ the agenda such that "talk that is grounded in fragmented or marginalized discourses . . . is read as idiosyncratic or personal comment, having no political force." 251

A statutory regime is therefore necessary to obligate judges to con-

${ }^{246} I d$

${ }^{247}$ Jody Armour asserts that “[r]ace-based predictions of an individual's behavior insufficiently recognize individual autonomy by reducing people to predictable objects rather than treating them as autonomous entities." Armour, supra note 211, at 795. Ignoring racial identity and the existence of racial stressors by assuming all people will or should react uncritically according to the dictates of a white norm similarly disregards the autonomy of people of color.

${ }^{248}$ See id. (" $[\mathrm{H}]$ astier use of force against blacks forces blacks who do not want to be mistaken for assailants to avoid ostensibly public places (such as 'white' neighborhoods, automatic tellers, and even Manhattan boutiques) and core community activities (such as shopping, jogging, sightseeing, or just 'hanging out')."); $i d$. (stating too that this "hastier use of force" thus interferes with "the fullness of [African Americans'] public, participatory selves" (quoting PatRicia J. Williams, THE Alchemy of RaCE AND RIGHTS 46 (1991) (alteration in original))).

${ }^{249}$ See id. at 794 ("Ultimately, the courts' reliance on statistical generalizations may provide an official imprimatur on stereotypes about the class in question.... [C]ountenancing race-based statistics might further entrench stereotypes about blacks as criminals in the public's collective consciousness.").

${ }^{250}$ Miller, supra note 199 , at 159.

251 Id. at 163 (citation omitted). 
textualize the plaintiff-police interaction in light of the nexus between the plaintiff's racial background and her experiences with the police. The purpose of such a regime would not be to legitimize behavior that is otherwise unreasonable (viewed as such because it is atypical from the majority's perspective), but to establish that the plaintiff's defensive reaction to the police was not unreasonable in the first place, given the pervasive racism manifest in police protocol. When a person of color is subject to police misconduct, a court's decision to provide remedies must aim at redressing an injustice affecting the recognized and respected rights of the victim. The court's rationale should not be to forgive a plaintiff for behavior inappropriately conceived of as being anomalous. Labeling the experiences that many people of color have with police as abnormal (e.g., equivalent to a disability, or to any other concept used to legitimize behavior) undermines the validity of such experiences and normalizes abusive behavior by police. It requires that plaintiffs of color portray themselves as anomalous to secure the special procedural treatment needed to increase the likelihood of successfully suing errant police. In short, one must be "crazy" in order to sue the police and win.

\section{Why Proposal Two Is Necessary: Revising the Statute to Emphasize Societal Racism}

There is a need to acknowledge racism's effect on the individual psyche. Expanding the ADA's definitions of mental illness to include racially discriminatory stressors may be worthwhile if it offers the traumatized victim of color one more cause of action with which to demand equal treatment-an ADA claim.

Proposal One, however, is an inadequate proposal standing alone. It places the emphasis on the victim's psyche rather than on the nature of the injustice, thus deflecting the determinative inquiry away from whether there was a police-related injustice and toward a spurious focus on the legitimacy of the plaintiff's reaction. Furthermore, acknowledging the effect of race on the individual is problematic if not accompanied by an acknowledgement of racism's effect on society as a whole. This leads to people confusing the traumatized individual of color with the healthy person of color responding to societal racism. A serious approach to police misconduct must first and foremost recognize that racism exists and routinely affects people of color, even when its victims do not respond to it by developing mental illnesses. The legal system must recognize that the reactions of people of color to police misconduct are often reasonable responses to socie- 
tal racism and not anomalous manifestations of a damaged psyche. As such, a race-conscious means of addressing societal racism and its manifestations in police conduct is necessary to protect not only the rights of people of color with stress disorders, but also to protect those who, even though they have not developed diagnosed stress disorders, still suffer from the same racist externalities. Proposal Two accomplishes this goal.

1. A Blueprint for Making the Advantages of the ADA Available so as to Benefit Plaintiffs of Color

Proposal Two distills the useful procedural properties of the ADA and makes their advantages accessible to victims of color. By omitting the disability rhetoric while retaining the procedural benefits that overcome the problems arising out of the application of $\$ 1983$, it becomes possible to fuse the best of both statutes. A $\S 1983$ /ADA hybrid would offer the procedural advantages of the ADA to the intended beneficiaries of traditional $\$ 1983$ police misconduct suits. The ADA's procedural advantages $^{252}$ need not be limited to the context of ADA claims alone.

A new police misconduct statute should therefore set forth the following advantages, discussed above in the context of the $\mathrm{ADA},{ }^{253}$ or some combination thereof: (1) safeguards preventing government entities from escaping liability through qualified immunity and interlocutory appeal; (2) respondeat superior liability for officers' actions instead of the current Monell liability; (3) requirements for selfevaluation and modification internal to the police misconduct statute itself; (4) an assignment of affirmative duties to police to ensure that persons apprehended are cared for properly when taken into custody; (5) assignment of affirmative duties to both public and private correctional institution officers to avoid violating prisoners' rights under the proposed statute; and (6) stipulations permitting successful plaintiffs to receive broad recovery of litigation expenses.

In addition, the statute should effectuate a race-conscious approach by including: (7) a judicial obligation to take the race of the plaintiff into account when considering interactions with the police. Speaking with respect to African Americans in particular, Professor Butler suggests that it is entirely appropriate, if not necessary, that they cite as evidence "their own experiences and other people's sto-

${ }_{252}^{252}$ Supra Part II.B.
${ }_{\text {Id }}$. 
ries, African-American history, understanding gained from social science research on the power and pervasiveness of white supremacy, and ugly statistics ${ }^{2054}$ when analyzing the American system of justice. ${ }^{255}$ The more informed and comprehensive a judge's examination of the racial context surrounding a particular interaction-that is, as the judge expands her inquiry to consider the types of evidence Professor Butler mentions-the more likely it is that evidence will emerge to indicate that the particular plaintiff of color has been exposed to some experience that would reasonably engender a distrust of the police system in this country.

Because judges are often unprepared or unwilling to expand their inquiry to such a degree, they are unlikely to consider the "reasonable man" to be influenced by such evidence. ${ }^{256}$ Furthermore, the reasonable person test is prone to misapplication: a judge who refuses to consider the evidence suggested by Professor Butler is unlikely to refrain from simply condemning the response of a plaintiff of color to police misconduct as a "character flaw"

${ }^{254}$ Butler, supra note 209, at 691.

${ }^{255}$ The Supreme Court will sometimes allow a plaintiff to offer statistical and circumstantial evidence to create a rebuttable, prima facie case that race is a motivating factor of a government action. See Batson v. Kentucky, 476 U.S. 79, 96 (1986) (holding that a defendant may establish a prima facie case of purposeful discrimination in selection of the petit jury solely on evidence concerning the prosecutor's exercise of peremptory challenges at the defendant's trial by showing membership in a cognizable racial group, that the prosecutor has exercised peremptory challenges to remove from the venire members of the defendant's race, and that the facts and any other relevant circumstances raise an inference that the prosecutor excluded veniremen from the petit jury on account of their race). Even the Batson opinion, however, would not necessarily obligate a judge to consider the type of evidence Butler mentions, such as the plaintiff's experiences of societal racism and white supremacy, or prior experiences of the same among police officers.

${ }^{256}$ David Cole discusses the problems of relying on judicial conceptions of a "reasonable person." COLE, supra note 6, at 16-27. In United States $v$. Mendenhall, 446 U.S. $544,555(1980)$, a traveler stopped by police in an airport and asked to show his identification was not "seized" by the encounter because the Court decided that a "reasonable person" would feel free to walk away. With that standard in mind, Cole considers Bostick v. State, 554 So. 2d 1153, 1158 (Fla. 1989), in which a young black man sleeping on the back of a cross-country bus was awakened and asked whether two sheriff's officers could search his bag. Bostick consented, and the officers claim to have found cocaine in his bag. Cole notes that "[f]ew of us, awakened in the middle of a marathon bus ride by armed police officers standing over us, asking for our identification and requesting to search our bags, would feel free to tell the officers to mind their own business." He surmises, "the Supreme Court's 'reasonable person' apparently has a lot more mettle than the average Joe." COLE, supra note 6 , at 18. "[T]his standard will have very different effects ... on minority and white citizens." Id. at 20 .

${ }^{257}$ See Armour, supra note 211, at 789 ("[T] he actual moral norm implicit in the reasonable man test is that blame is reserved for persons who fail to overcome charac- 
cordingly, it is necessary to secure through statutory protection the plaintiff's ability to draw on such evidence while still being considered a "reasonable man [or woman]."

\section{A Race-Conscious Statute Is Necessary Because the Current Statutory Interpretations Provide a Mistaken Impression of Racial Equality}

The Supreme Court has determined that race is a suspect class such that allegedly racially discriminatory laws require strict equal protection scrutiny, ${ }^{258}$ while, for instance, laws affecting people with mental disabilities do not even merit mid-tier equal protection scrutiny. ${ }^{259}$ Ironically, the Supreme Court's heightened vigilance against racial discrimination has resulted in a statutory regime that facilitates remedies for people with disabilities more than it does for people of color with respect to police misconduct. ${ }^{260}$ This overlooks the very groups of people who are among those most likely to need statutory protection-people of color. ${ }^{261}$

ter flaws that they can fairly be expected to surmount for the sake of important social interests." (citing George P. Fletcher, The Individualization of Excusing Conditions, $47 \mathrm{~S}$. CAL. L. REV. 1269, 1291 (1974)))

${ }^{258}$ See Korematsu v. United States, 323 U.S. 214, 216 (1944) ("It should be noted ... that all legal restrictions which curtail the civil rights of a single racial group are immediately suspect."); Yick Wo v. Hopkins, 118 U.S. 356, 373-74 (1886) (holding that the underlying law was constitutional but the actions of those in power in applying the law were discriminatory toward Chinese Americans and thus unconstitutional). Korematsu is ironic given that it actually disadvantaged Japanese Americans. Indeed, even when measures are taken to remedy discrimination against racial groups subject to oppression, strict scrutiny still applies. For instance, the Supreme Court held in City of Richmond v. J.A. Croson Co., 488 U.S. 469 (1989), that absent proof of specific instances of discrimination, laws attempting to effect an outright racial balancing will be struck down:

[T] he purpose of strict scrutiny is to "smoke out" illegitimate uses of race by assuring that the legislative body is pursuing a goal important enough to warrant use of a highly suspect tool. ... [T] he standard of review under the Equal Protection Clause is not dependent on the race of those burdened or benefitted by a particular classification.

Id. at 493-94 (citations omitted). But see Washington v. Seattle Sch. Dist. No. 1, 458 U.S. 457, 485 (1982) (noting that "every attempt to address a racial issue [will not necessarily give] rise to an impermissible racial classification").

259 See City of Cleburne v. Cleburne Living Ctr., Inc., 473 U.S. 432, 442-47 (1985) (declining to use heightened scrutiny on the grounds that the mentally disabled are not considered a protected class).

${ }^{260}$ See supra Part II (describing the advantages the ADA has for people with disabilities that $\$ 1983$ does not offer to plaintiffs of color subject to police misconduct).

${ }^{261}$ See supra note 8 and accompanying text (documenting the fact that people of color are disproportionately subject to police misconduct). 
A new statute is necessary not only to hold the judiciary true to the legislature's professed intentions to effect equal protection, but also to avoid frustrating the legal and political claims of plaintiffs of color, recognizing that "'democracy,' as practiced in the United States, has betrayed African-Americans [and arguably other people of color as well] far more than they could ever betray it." ${ }^{262}$ Professor Butler articulates a view characteristic of Critical Race Theory, pointing out that "black jurors symbolize the fairness and impartiality of the law" even if those black jurors endorse racial critiques of American criminal justice. ${ }^{263}$ Butler refers to this role of black jurors as the "legitimization function." a democracy and a pluralist society, it is important that diverse groups appear to have a voice in the laws that govern them." When an appearance of a voice is coupled with impotence in practice, however, that appearance is often used to instill complacency in the face of an inequitable distribution of justice and to justify inaction in support of the inequitable status quo. In such a situation, "[i]t would be farcical for [a black juror] to be the sole color-blind actor in the criminal process, especially when it is her blackness that advertises the system's fairness."

The above discussion of the lack of effective statutory protection of plaintiffs of color in police misconduct cases and the simultaneous nominal protections against racial discrimination understood to be embodied by $\$ 1983$ suggest a situation analogous to Butler's discussion of the role of black jurors who are critical of the American system of jurisprudence. Butler's reasoning is accordingly poignant if extended to address police misconduct. He writes:

What does "viable democracy" assume about the power of an unpopular minority group to make the laws that affect them? It assumes that the group has the power to influence legislation. The American majorityrule electoral system is premised on the hope that the majority will not tyrannize the minority, but rather represent the minority's interests. Indeed, in creating the Constitution, the Framers attempted to guard

${ }^{262}$ Butler, supra note 209, at 706; see also GRIER \& COBBS, supra note 21, at 144 ("All Americans feel committed to the principle of 'all men, created equal,' but it does not occupy a central position in their view of their place in America. It is a case of "All men are born equal, but white men are more equal than anyone else."').

${ }^{263}$ Butler, supra note 209 , at 712.

${ }^{264}$ Id. The use of the term "legitimize" in Part IV.B supra and elsewhere in this Comment is not related to Butler's use of the term here.

${ }^{265}$ Id.

${ }^{266} I d$. at 714 . 
against the oppression of the minority by the majority. Unfortunately, these attempts were expressed more in theory than in actual constitutional guarantees....

....

. . . Resistance by minorities to the operation of majority rule may take several forms, including "overt compliance and secret rejection of the legitimacy of the political order. ${ }^{267}$

Arguably, "odd" reactions to the police may constitute just such resistance, and may even represent involuntary or reflexive rejection of the notion that police promote the well-being of all citizens equally.

Efforts to acknowledge and respond to the circumstances prompting such resistance by promoting remedies for people of color specifically are met with criticisms that people of color are already protected, have the same opportunities available to them that whites have, and thus deserve no special accommodation. ${ }^{268}$ At the same time, the nominal protections afforded by $\S 1983$ threaten to render it a mere legitimizing tool with respect to police misconduct. A new police misconduct statute obligating judges to take the race of the plaintiff into account when considering an interaction between the plaintiff and the police is necessary to avoid that end.

3. A Race-Conscious Statute Would Better Ensure That the Anti-Discrimination Overtures of the Legislature

Are More Than Nominal

A Supreme Court majority has interpreted the legacy of the Civil Rights movement as a denunciation of race-conscious applications of the law. ${ }^{269}$ As discussed above, however, several judges and justices have taken race into consideration, recognizing that adverse reactions to the police based on race are not necessarily abnormal. ${ }^{270}$ But despite the legislature's nominal willingness to protect the civil rights of

${ }^{267}$ Id. at 710-11.

${ }^{268}$ William Grier and Price Cobbs further note:

Americans are characteristically unwilling to think about the past. . . [T] hese attitudes ... bring white Americans to an impasse when they claim to "understand" black people. After all, the thoughts begin, the Negro is also an American and if he is different it is only a matter of degree. Clichés are brought forth and there is a lengthy recitation of the names of famous $\mathrm{Ne}$ groes.

GRIER \& COBBS, supra note 21, at 23.

${ }^{269}$ See supra note 258 (discussing the Supreme Court's opinion in City of Richmond

v. J.A. Croson, Co., 488 U.S. 469 (1989)).

${ }^{270}$ See supra notes 238-42 and accompanying text (providing examples). 
people of color, ${ }^{271}$ the hands of judges have been tied. Judges who engage in race-conscious critiques of police, by recognizing that people of color are disproportionately subject to the "corrupt, abusive and violent" spate of police misconduct, are denounced as judicial activists amidst a volley of misdirected political aspirations. ${ }^{272}$ This suggests that judges could administer justice more efficiently and clearly if they had a statutory reference point to support them.

A new statute is therefore necessary to reconcile legislative intent with practical effect. A statute effectively curbing police misconduct directed at people of color, however, must be race conscious. Otherwise, further legislation is unlikely to have any effect. Malcolm X repeatedly noted, even in the $1960 \mathrm{~s}$, that there were plenty of laws in place that could be interpreted to assert the rights of people of color if those in power had any intention to do so. ${ }^{273}$ Judges are already obligated to look at how a reasonable person would respond to the particular facts and context of the case at hand, but the results remain bi-

${ }^{271}$ See supra note 79 and accompanying text (discussing the text of the $\$ 1983$ civil rights statute).

${ }^{272}$ United States v. Bayless, 201 F.3d 116, 122-23 (2d Cir. 2000) (recounting that, in reaction to Judge Baer's ruling in the case, in which he acknowledged the community's perception of the police as "corrupt, abusive and violent," (quoting United States v. Bayless, 913 F. Supp 232, 242 (S.D.N.Y. 1996)), "more than two hundred members of Congress, led by Republican Representatives Bill McCollum, Fred Upton, and Michael Forbes, sent a letter to President Clinton calling Judge Baer's ruling 'a shocking and egregious example of judicial activism." (citing Jon O. Newman, The Judge Baer Controversy, 80 JUDICATURE 156, 156 (1997))); see also supra notes 243-44 and accompanying text (discussing the impact the upcoming Presidential election had on the judge's opinion).

${ }^{279}$ Malcolm X commended the outlook of the black person who "doesn't see any progress that he has made since the Civil War ... because ... if the Civil War had freed him, he wouldn't need civil-rights legislation today." He continued, "[i]f the Emancipation Proclamation ... had freed him, he wouldn't be singing 'We Shall Overcome' today. If the amendments to the Constitution had solved his problem, his problem wouldn't still be here today." Malcolm X, The Black Revolution, Speech at the Militant Labor Forum at Palm Gardens in N.Y.C. (Apr. 8, 1964), in MALCOLM X SPEAKS: SElECTED SPEeCHES AND STATEMENTS 45, 52-53 (George Breitman ed., 1990).

Such criticisms are equally apropos today, if not more so. Consider the following criticism, written over thirty years ago, which still resonates in current times:

In spite of the profound shifts in power throughout the world in the past thirty years, the United States seems to have a domestic objective of "business as usual," with no change needed or in fact wanted. All the nasty problems are overseas. At home the search is for bigger profits and smaller costs, better education and lower taxes.... Problems at home are to be talked away, reasoned in to nonexistence, and put to one side ....

GRIER \& COBBS, supra note 21, at 203. 
ased against people of color. ${ }^{274}$ Judges already have statutes available to them to punish police, ${ }^{275}$ but they choose not to-judges allow police misconduct to continue. ${ }^{276}$

In order to avoid the impotence of previous civil rights laws, an explicitly race-conscious rule is necessary to hold judges accountable in no uncertain terms for refusing to acknowledge that race plays a role in police encounters. A serious commitment to ensuring that the constitutional rights of plaintiffs of color are honored in fact (not just in theory) requires a statute mandating that judges contextualize plaintiffs' claims by looking explicitly at the effects that the plaintiffs' race may have on interactions with, and treatment by, the police. In other words, securing adequate protection for people of color with respect to police misconduct requires a statute designed not as a call for greater judicial independence, but rather for judicial accountability. ${ }^{277}$

\section{Statutory Revision Would Benefit Officers as Well}

A new police misconduct statute, as outlined above, would also offer advantages to the police officers themselves. First, it would boost police morale by facilitating increased community appreciation of police presence. If municipalities or states incur liability for the actions of their employee officers, it will be in the best interest of police departments to emphasize that officers are personally accountable for their conduct. Even if the officers are not named as defendants, police departments will be more inclined to impose internal means of discouraging misconduct if the departments themselves are held liable. In turn, officers will be discouraged from protecting errant col-

${ }^{274}$ See supra note 256 (describing the court's application of a reasonable person standard to the detriment of people of color).

${ }^{275}$ There are many causes of action codified at 42 U.S.C. $\$ \S 1981,1982,1985$, and 1986, which initially promised great leaps toward true equal protection, and which could be interpreted without straying very far from their literal meaning to hold police more accountable for their actions. Rather, the practical efficacy of democratically voiced mandates of equal protection is retarded largely by caselaw.

${ }^{276}$ "By failing to consider the citizen's prior experiences with the police in determining whether a 'seizure' has occurred," for example, "the Court permits the police to employ, on average, more coercion against black persons than against whites," such that "the same police conduct will be more threatening when directed against a black man than when directed against a white man." CoLE, supra note 6, at 26-27.

${ }^{277}$ As it stands, judges have leeway to engage in bias unchecked. See, e.g., Spann, supra note 192, at 4 (arguing that "the issue of how societal resources should be allocated between the majority and racial minorities is an issue ... [in which] Supreme Court involvement ... provides an artificial boost to the interests of the white majority" (citation omitted)). 
leagues if they know that they are more likely to be held accountable for "covering up" misconduct, and, alternatively, that they are commended for stepping forward to expose such misconduct. The "Blue Wall of Silence," a serious impediment to just law enforcement, ${ }^{278}$ will thereby begin to crumble. ${ }^{279}$ This will benefit the policed community by encouraging a more honest and transparent police force, and by facilitating familiarity and trust among officers and the individuals they are intended to protect and serve. In return, officers who have reason to believe that the community in which they work appreciates and respects their presence, rather than views them suspiciously, will experience an increase in morale.

Second, officers stand to benefit more directly from an erosion of the "Blue Wall of Silence." Many officers are uncomfortable and unwilling to perpetuate informal codes of silence. ${ }^{280}$ Discouraging codes of silence would alleviate the worry among officers that they may offend colleagues and endanger themselves by not being complicit in misconduct. ${ }^{281}$ A statutory mechanism honored by the courts and the precincts to address misconduct would prevent the burden of exposing unsafe or illegal police activity from falling on the shoulders of honest officers alone. Furthermore, officers of color are themselves

${ }^{278}$ See BURRIS, supra note 8, at 178 ("The single most tenacious obstacle to reform in police departments across the nation is what is known as the 'blue wall,' or the 'code of silence." ).

${ }^{279}$ The "Blue Wall of Silence" is so entrenched in police culture that an officer recently filed suit claiming that it was his constitutional right to have other officers cover up his misconduct. When other officers did not cover up for him, plaintiff sued based on selective enforcement, claiming injuries of ostracism, alienation of friendships, and the withholding of preferential treatment by fellow police. Diesel v. Lewisboro, 232 F.3d 92 (2d Cir. 2000).

${ }^{280}$ See BURRIS, supra note 8 , at 38 ("I've talked to many police officers who felt sickened by what they had seen a brutal cop do, but the price for speaking out was simply too high."); Jeffrey Goldberg, The Color of Suspicion, N.Y. TIMES, June 20, 1999, (Magazine), at 50, 85 (claiming that police, including black officers, will admit in private that racial "tunnel vision" is a hazard of the job). One officer's experiences with a code of silence were considered sufficiently dramatic to be memorialized in the film SERPICO (Paramount Pictures 1973) (based on the 1973 book by Peter Maas), in which Al Pacino plays the role of Officer Frank Serpico, who ultimately resigned from the New York Police Department after testifying about police corruption among his colleagues before the Knapp Commission. Because of his whistleblowing, his fellow officers did not back him up in a raid, and he was shot as a result. He resigned in 1972 after twelve years of service.

${ }^{281}$ See Leonard Sykes, Jr. \& James H. Burnett, III, The Long Arm of Racial Profiling, MilWAUKEE J. SENTINEL, Mar. 24, 2001, at 1B ("While most officers surveyed argued that profiling as a practice is inherently wrong, many expressed concern that their responses [to a University of Wisconsin-Milwaukee survey about racial profiling] could be misconstrued as being disloyal and anti-police."). 
also subject to misconduct, and have voiced their opposition to its perpetuation. ${ }^{282}$

Third, officers and the community benefit from admonishing errant officers since police misconduct is often perpetrated by repeat offenders. ${ }^{283}$ Identifying problematic officer conduct after an initial offense and removing governmental immunities would: (1) prevent further incidents of brutality by that officer and thereby help reduce the stigma cast on the officer's innocent colleagues; (2) allow the offending officer to receive treatment and better training; (3) save local taxpayers from bearing the costs of redundant lawsuits on behalf of the municipality; ${ }^{284}$ and (4) avoid subjecting citizens to substandard police protection at the hands of disgruntled officers with a grudge

${ }^{282}$ See David Kocieniewski, Bias Permeates the State Police, Whitman Admits, N.Y. TimES, July 3, 1999, at A1 (discussing an officer who complained of hostile treatment at the workplace in the form of "racial discrimination and sexual harassment"); Officers Take on Department over Race Issues: Investigation of San Jose Detective's Comment About Stopping Blacks Nears Completion, SAN JOSE MERCURY NEWS, June 5, 2000, at 1A ("Energized by the national campaign to condemn racial profiling . . . some [black officers] have crossed the thin blue line to make their battle public."); Nina Shapiro, Black and Blue: African-American Law Enforcement Officials Feel Caught Between Two Worlds, SEATTLE WKLY., June 21, 2001, at 13 ("African Americans have predominated at the ongoing protests and forums over the fatal police shooting of Aaron Roberts."); Sykes \& Burnett, supra note 281, at 1B (according to one officer of color discussing how he is treated by white officers, " $[w]$ hat happens ... is that when you're in your street clothes you no longer have your blue uniform on [; b] ut what you do have on is your blackness-the fact that you're African-American"). The Kocieniewski article also relates such incidents as

female troopers who said their commander had referred to them using vulgar descriptions of female genitalia, black officers who said they had been frequently demeaned by racial slurs, and a Hispanic officer who said he had been verbally harassed and abandoned on a roadway after having been stripped down to his underwear by fellow troopers.

Kocieniewski, supra. And the Shapiro article additionally notes:

Carlos Bratcher, president of the black officers' association and a detective in the King County sheriff's office, says it's important for people to realize that the 'minority community isn't just crying wolf' regarding police racism, particularly when it comes to racial profiling. . . . [He] believes he was himself needlessly stopped . . . when he was more informally dressed and driving offduty.

Shapiro, supra.

${ }^{283}$ See, e.g., BURRIS supra note 8 , at 72 ("In Oakland, I have repeatedly encountered the same cops in civil cases involving brutality; there was one officer who was the subject of 37 investigations before he eventually left the force."); INDEP. COMM'N ON THE L.A. POLICE DEP'T, REPORT, at iii (1991) ("There is a significant number of officers in the LAPD who repetitively use excessive force against the public and persistently ignore the written guidelines of the Department regarding force.").

284 "A recent report stated that [New York] City has paid $\$ 176.9$ million to dispose of more than 3,500 police misconduct lawsuits since 1994." GREEN, supra note 29, at 2. 
against the communities they patrol. It should be emphasized that removing immunity does not place innocent officers at a disadvantage-they, like all other citizens, are innocent until proven guilty, and the courts and juries will afford them no less impartiality than they afford all other defendants.

Finally, the explicitly race-conscious aspect of the proposed statute would not be unduly difficult for officers to heed. While many people are of indeterminate racial background upon first glance (and acknowledging the argument that race is socially constructed anyway), officers identify people as nonwhite all the time. Indeed, if officers could not make racial determinations, there would be no racial discrimination in the first place-it is apparent that officers make racial determinations because they single out people of color for misconduct. Furthermore, the ADA already obliges officers to treat PTSD sufferers with care, and determining that someone is nonwhite is generally easier than determining whether or not someone has PTSD upon first glance. ${ }^{285}$

\section{ANTICIPATING AND AdDRESSING SOME Potential GRITICISMS OF ENACTING NEW POLICE MISCONDUCT LEGISLATION}

\section{A. Responding to the Fear That a Race-Conscious Police Misconduct Statute Would Encourage Justifying Racist Crimes by Whites}

Critics may argue that by allowing the judge to consider race in context, such a statute would implicitly support using race to justify otherwise inordinate aggression toward people of color by white civilians or by white police officers. The response to that criticism is unfortunate, but not novel: whites already successfully use race to justify to the court inordinate, and often violent, behavior toward people of color. $^{286}$ "Indeed," writes Jody D. Armour, "it has been well-

${ }^{285}$ While it would be impractical to require every officer to obtain a functional proficiency in identifying PTSD comparable to that obtained by acquiring a degree in psychology, determining race is feasible. Officers often must make snap judgments about a suspect's psychological profile, despite the fact that officers historically are wary of psychological evaluation. See Talbott \& Talbott, supra note 187, at 898-99 (noting that officers have been reticent about accepting the consultation services of psychiatrists, especially when those services are applied in order to evaluate the police themselves). Similarly, even officers who are critical of having to pay explicit attention to race may nonetheless be expected to do so.

${ }^{286}$ An analogous argument has been used by Professor Butler in responding to the claim that supporting jury nullification by black jurors as a means of resisting a criminal justice system of which those jurors are critical will lead to whites nullifying in cases 
documented that defendants in self-defense cases exploit the racial prejudices of jurors in asserting the reasonableness of their fear of supposed assailants who are black." 287

of white-on-black crime. Butler's response is that "white people do nullify in those cases." Butler, supra note 209, at 722.

${ }^{287}$ Armour, supra note 211, at 783. Armour offers a hypothetical example: if a woman at an automatic teller machine late at night sees a black man approaching and shoots him in a fit of panic, thinking he is a criminal based on a previous traumatic experience in which she had been assaulted by a black man, "she might claim that her overreaction to the victim's race was reasonable in light of her earlier traumatic experience." Id. at 782; see also, e.g., People v. Goetz, 520 N.Y.S.2d 919, 919 (1987) (sentencing Bernhard Goetz to a split sentence of only six months after shooting a group of black boys on a subway, and discussing his desire to defend himself in a "high-crime area"). While a list of anecdotes would be unduly burdensome and beyond the scope of this Comment, Cynthia Kwei Yung Lee offers a powerful selection of cases that indicate how stereotypes and racist justifications have been applied to exculpate violent crimes by whites against people of color. See Cynthia Kwei Yung Lee, Race and SelfDefense: Toward a Normative Conception of Reasonableness, 81 MINN. L. REv. 367, 369 (1996) (examining "the topic of race and self-defense through the lens of socially constructed stereotypes about Blacks, Asian Americans, and Latinos" (footnotes omitted)). Lee discusses the case of Vincent Chin, a Chinese American who was beaten to death with a baseball bat by a white father-son pair to such an extent that pieces of brain matter were splattered on the pavement. Chin's race was at issue in the attack, his assailants calling him a "nip" and telling him that "it's because of you little mother fuckers that we're out of work." The judge sentenced the defendants to three years of probation and a $\$ 3780$ fine, saying "'Had it been a brutal murder, those fellows would be in jail now." Id. at 431-32 (quoting Dana Sachs, The Murderer Next Door, MOTHER JONES, July/Aug. 1989, at 54 (emphasis added by Lee)).

In 1992, a Louisiana homeowner shot and killed Yoshihiro Hattori, a sixteen-yearold Japanese foreign exchange student. Hattori, accompanied by his white friend, and dressed in a tuxedo as a character from the movie SATURDAY NIGHT FEVER (Paramount Pictures 1977), mistakenly rang the defendant homeowner's doorbell while looking for a nearby Halloween party. Without asking any questions, the homeowner emerged from the house with a laser-scoped .44 magnum and within three seconds shot and killed Hattori. The homeowner's acquittal from a charge of manslaughter-not murder-was received by the applause of courtroom spectators after less than three hours of deliberation. The homeowner's attorney played on racist characterizations of the Japanese "enemy," telling the jury, for example, that Hattori was acting menacingly, "like a stranger invading someone's home turf." Lee, supra, at 432-37 (quoting Defense Depicts Japanese Boy as 'Scary', N.Y. Times, May 21, 1993, at A10). The homeowner's wife, who first alerted her husband to Hattori's presence, said "I guess he appeared Oriental. He could have been Mexican or whatever." Id. at 437 (quoting Testimony of Bonnie Peairs at 22, State v. Peairs (May 22, 1993) (on file with Lee)). Lee points out that "[a]ll [Bonnie Peairs] knew was that Hattori looked different,' foreign," $i d$. at 438, and that if Hattori's white companion had been shot instead, "the defense would have had a more difficult time portraying the victim as 'a crazy man,' 'frightening,' or 'scary,' terms used to describe Hattori," id.

Lee also describes the case of Cesar René Arce and David Hillo, two young Mexican Americans shot by a passing white pedestrian civilian carrying a loaded, unlicensed gun who found them spray painting a freeway column. Id. at 445 . The gunman claims he thought the boys were behind him and that he turned and fired in self-defense. Id. 
In short, unless the present state of the law is adjusted, assaults on people of color will remain successfully justified by racial stereotypes in the courts, while the nonviolent reactions of people of color to police officers will remain unjustifiable by virtue of a legacy of racist police.

\section{B. Responding to the Colorblind Critique on Its Own Terms: Debunking the Contention That Contextualizing Race in Police Interactions Is Itself Racist}

Those embracing a colorblind approach to law, politically conservative critics, and critics disputing the relevance or reliability of the anecdotal evidence offered above, predictably will argue that requiring a judge to consider the impact of the plaintiff's race on her reaction to the police (or on the police's treatment of the plaintiff) makes it alright for a plaintiff to defy the police by "playing the race card." That is, these critics will argue that a new police misconduct statute like that described above would unfairly offer people of color special treatment because of their race alone.

Such criticisms, however, would not apply to the proposed police misconduct statute, even if one were to concede the validity of a colorblind stance, because there is a distinction between engaging in racist beliefs about others and responding to the racist beliefs of others. The proposed police misconduct statute would facilitate protecting plaintiffs' responses to racism; it would not protect engaging in racist behavior. A new police statute would not require that a plaintiff of color's reaction be excused because of the plaintiff's fear of the race of the officer. Rather, the plaintiff's reaction would be a response to officers' race-based apprehensiveness of the plaintiff, regardless of the officer's race. (Officers of color, after all, are often guilty of engaging

at 446 . The boys were shot in the back and buttocks (killing Arce), and could not have been approaching the gunman. Id. Lee notes that while the Los Angeles District Attorney's Office declined to prosecute the gunman, the same District Attorney's Office "filed murder and manslaughter charges against two Black men ... who claimed they shot another Black man in self-defense, disbelieving their self-defense claim largely because the victim was shot in the back and buttocks." Id. at 446-47. The gunman was hailed as a local hero by a neighboring councilwoman. Id. at 448 . Lee contrasts Arce's death with the public outrage at the four-month prison sentence, fine, and caning of Michael Fay, a white American teenager caught vandalizing in Singapore. "If a Singaporean citizen had shot and killed Fay after catching him in the act of spray-painting the Singaporean citizen's car, it is unlikely that Americans would view the Singaporean as a hero ...." Id. at 450-51. 
in racist police misconduct also. ${ }^{288}$ Plaintiffs of color are therefore often wary of officers regardless of their race.) A new police statute would allow the judge to admit as reasonable the plaintiff's reaction to, not her submission to, race-based fears.

The critic may respond that for a plaintiff to assume that another individual harbors race-based fears itself constitutes a racist belief and exhibits a race-based fear. Even if this were true, that argument would apply only to the act of anticipating that another individual is racist because she is of a particular race. It would not apply to a plaintiff anticipating that another individual is racist because of her occupation as a police officer.

It is therefore not inconsistent to argue in support of a new statute that permits judges to consider the race of the plaintiff in context, while criticizing decisions that permit white defendants who assault people of color to justify their actions based on race-based fears. A new police statute would obligate the judge simply to consider that adverse reactions to racism are reasonable. It would not permit or encourage judges to claim that racist beliefs justify otherwise unreasonable behavior toward other persons.

\section{CONCLUSION}

Police misconduct is a serious problem in the United States, adversely affecting people of color in particular. Although there appears to be a legislative desire to provide a remedy for such discriminatory behavior, evidenced by the enactment of $\$ 1983$, traditional criminal and civil remedies for police misconduct have proven inadequate, leaving counsel for plaintiffs in search of more creative, more effective methods of representing clients victimized by police. As a result, the ADA has been suggested as an alternative in police misconduct litigation. Taken separately, however, and subject to the prevailing colorblind judicial interpretation, neither $\S 1983$ nor the ADA offers an adequate litigation tool for causes of action by people of color who are victims of police misconduct.

This Comment has considered how the implications of a comparison between $\S 1983$ and the ADA testify to the need for a raceconscious means of facilitating the claims of people of color who file

288 See, e.g., Michael P. Tremoglie, Cops in the 'Hood', FrontPaGe MaG. (Feb. 15, 2001), at http://www.frontpagemag.com/columnists/tremoglie/2001/trem02-1501.htm ("Minority police officers are often tougher on their own people than white cops."). 
suit for police misconduct. By combining the procedural benefits of the ADA with the civil rights rationale underlying $\$ 1983$ in a raceconscious manner, it may be possible to close the statutory gap that currently deprives many people of color of an effective means of pursuing police misconduct litigation. 